OPEN ACCESS

Edited by: Andrew F. James,

University of Bristol, United Kingdom

Reviewed by:

Giuseppe Remuzzi,

Mario Negri Pharmacological

Research Institute (IRCCS), Italy

Paolo Madeddu,

University of Bristol, United Kingdom

*Correspondence:

Georgina M. Ellison-Hughes georgina.ellison@kcl.ac.uk

Specialty section:

This article was submitted to Cardiovascular Biologics and

Regenerative Medicine,

a section of the journal

Frontiers in Cardiovascular Medicine

Received: 02 September 2020

Accepted: 17 November 2020

Published: 09 December 2020

Citation:

Ellison-Hughes GM, Colley L,

O'Brien KA, Roberts KA,

Agbaedeng TA and Ross MD (2020)

The Role of MSC Therapy in

Attenuating the Damaging Effects of

the Cytokine Storm Induced by

COVID-19 on the Heart and

Cardiovascular System

Front. Cardiovasc. Med. 7:602183.

doi: 10.3389/fcvm.2020.602183

\section{The Role of MSC Therapy in} Attenuating the Damaging Effects of the Cytokine Storm Induced by COVID-19 on the Heart and Cardiovascular System

\author{
Georgina M. Ellison-Hughes ${ }^{1 *}$, Liam Colley ${ }^{2}$, Katie A. O'Brien ${ }^{3}$, Kirsty A. Roberts ${ }^{4}$, \\ Thomas A. Agbaedeng ${ }^{5}$ and Mark D. Ross ${ }^{6}$
}

\begin{abstract}
${ }^{1}$ Faculty of Life Sciences \& Medicine, Centre for Human and Applied Physiological Sciences, School of Basic and Medical Biosciences, King's College London Guy's Campus, London, United Kingdom, ${ }^{2}$ School of Sport, Health, and Exercise Sciences, Bangor University, Bangor, United Kingdom, ${ }^{3}$ Department of Physiology, Development, and Neuroscience, University of Cambridge, Cambridge, United Kingdom, ${ }^{4}$ Research Institute for Sport and Exercise Sciences, Liverpool John Moores University, Liverpool, United Kingdom, ${ }^{5}$ Faculty of Health \& Medical Sciences, Centre for Heart Rhythm Disorders, School of Medicine, The University of Adelaide, Adelaide, SA, Australia, ${ }^{6}$ School of Applied Sciences, Edinburgh Napier University, Edinburgh, United Kingdom
\end{abstract}

The global pandemic of severe acute respiratory syndrome coronavirus 2 (SARS-CoV-2) that causes coronavirus disease 2019 (COVID-19) has led to $47 \mathrm{~m}$ infected cases and 1. $2 \mathrm{~m}(2.6 \%)$ deaths. A hallmark of more severe cases of SARS-CoV-2 in patients with acute respiratory distress syndrome (ARDS) appears to be a virally-induced over-activation or unregulated response of the immune system, termed a "cytokine storm," featuring elevated levels of pro-inflammatory cytokines such as IL-2, IL-6, IL-7, IL-22, CXCL10, and TNF $\alpha$. Whilst the lungs are the primary site of infection for SARS-CoV-2, in more severe cases its effects can be detected in multiple organ systems. Indeed, many COVID-19 positive patients develop cardiovascular complications, such as myocardial injury, myocarditis, cardiac arrhythmia, and thromboembolism, which are associated with higher mortality. Drug and cell therapies targeting immunosuppression have been suggested to help combat the cytokine storm. In particular, mesenchymal stromal cells (MSCs), owing to their powerful immunomodulatory ability, have shown promise in early clinical studies to avoid, prevent or attenuate the cytokine storm. In this review, we will discuss the mechanistic underpinnings of the cytokine storm on the cardiovascular system, and how MSCs potentially attenuate the damage caused by the cytokine storm induced by COVID-19. We will also address how MSC transplantation could alleviate the long-term complications seen in some COVID-19 patients, such as improving tissue repair and regeneration.

Keywords: COVID-19, mesenchymal stem cells, cytokine storm, cardiovascular, regeneration and repair 


\section{INTRODUCTION}

As of 3rd November 2020, there are $>47$ million cases of the coronavirus 19 or severe acute respiratory syndrome coronavirus 2 (SARS-CoV-2) that causes coronavirus disease 2019 (COVID$19)$ in the World. There have been $>1.2$ million reported deaths due to COVID-19, and $>34$ million infected cases have recovered. As it stands, the infection and death rate due to COVID-19 is below that of previous pandemics. For example, the 1918 Spanish flu outbreak saw 500 million people infected throughout the World and 17-50 million people died over a 2 year span; with up to 25 million deaths in the first 25 weeks (1). Prior to the 1918 flu pandemic, influenza outbreaks had only killed juveniles and the elderly or already weakened patients. However, the Spanish flu was killing completely healthy young adults, while leaving children and those with weaker immune systems still alive (2). This high mortality was attributed to malnourishment, overcrowded medical camps and hospitals, and poor hygiene, all exacerbated by the recent war which promoted bacterial superinfection (3). The outcome of the COVID-19 pandemic is impossible to predict, however history shows that past pandemics have reshaped societies in profound ways. It is clear that COVID-19 has already changed the World and the way we live and work forever.

SARS-CoV-2 gains entry to human cells through the angiotensin-converting enzyme 2, or ACE2 receptor (4). ACE2mediated viral entry is facilitated by serine proteases, most notably transmembrane protease serine 2 (TMPRSS2), which primes the SARS-CoV-2 spike glycoprotein (5). Initial infection of lung epithelia or alveoli allows SARS-CoV-2 to access the otherwise enclosed systemic circulation, subsequently predisposing multiple organs to potential infection. Multiple organs and tissues, such as the lungs, heart, kidneys, liver, and the vasculature, contain cells which co-express ACE2 and TMPRSS2, or other serine proteases (cathepsin B and cathepsin L1) (6-9).

Similar to other diseases caused by coronaviruses, the main transmission route of SARS-CoV-2 is via respiratory droplets and aerosolised particles (10) that are propelled into the air when a person speaks, coughs, shouts, sings, sneezes, or laughs. At the onset of the COVID-19 pandemic, the main symptoms were fever (98\%), cough (76\%), and myalgia or fatigue (44\%) (11). Then, loss of sense of taste and smell, termed anosmia, became a symptom in March 2020 (12), with a large proportion of those reporting anosmia presenting with mild symptoms. Patients can then develop breathing difficulty within 1 week and the severely ill patients soon developed acute respiratory distress syndrome (ARDS), acute cardiac injury, secondary infections, or a combination, resulting in hospital admission and severe cases requiring mechanical ventilation in the ICU (11). Such patients typically exhibit an exaggerated immune response, or cytokine storm, that has become a hallmark of severe SARS-CoV-2 infection. Suppressing the pro-inflammatory nature of the disease is critical to improving patient morbidity and mortality rates and, therefore, developing and identifying viable therapeutic strategies is of urgent scientific importance. Transplantation of mesenchymal stem/stromal cells (MSCs) is one such potential therapy to combat COVID-19 induced inflammation and regeneration of damaged tissues.

The merits of MSCs are that they are multipotent stromal cells that can differentiate into a variety of cell types, including osteoblasts, chondrocytes, myocytes, and adipocytes that have their own characteristic structures and functions of specific tissues. They are typically found in the bone marrow, but have also been characterized in the adipose tissue, dental pulp, umbilical cord tissue, amniotic fluid, and heart (13). Mesenchymal stromal cells are easily accessible from various tissues, are free from ethical issues and have demonstrated no adverse outcomes in clinical trials. They have high proliferation rates, can be systemically administered, and possess key stem cell properties, such as multipotency $(14,15)$, in addition to being effective immunomodulators, collectively making MSCs a promising therapy in improving COVID-19 morbidity and mortality.

\section{Old Age, Being Male and CVD Co-morbidity-Significant Risk Factors for Mortality}

Severity and high mortality from COVID-19 has been linked to old age, being male, cardiovascular disease (CVD), hypertension, and cardiometabolic disease including diabetes and obesity. A retrospective, multicentre cohort study by Zhou et al. (16) examined 191 patients, of whom 137 were discharged and 54 died in hospital. Of these patients, 91 (48\%) had a comorbidity, with hypertension being the most common [58 (30\%) patients], followed by diabetes [36 (19\%) patients] and coronary heart disease [15 (8\%) patients]. Multivariable regression analysis showed increasing odds of in-hospital death associated with older age [odds ratio (OR) 1.10, 95\% CI 1.03-1.17, per year increase; $p$ $=0.0043]$, higher Sequential Organ Failure Assessment (SOFA) score $(5.65,2.61-12.23 ; p<0.0001)$, and D-dimer $>1 \mu \mathrm{g} / \mathrm{mL}$ $(18.42,2.64-128.55 ; p=0.0033)$ on admission. In univariable analysis, odds of in-hospital death was higher in patients with diabetes or coronary heart disease. Age, lymphopenia, leucocytosis, and elevated ALT, lactate dehydrogenase, highsensitivity cardiac troponin I, creatine kinase, D-dimer, serum ferritin, IL-6, prothrombin time, creatinine, and procalcitonin were also associated with death (16).

In a retrospective case series involving 1,591 critically ill COVID-19 patients admitted from February 20 to March 18, 2020 in Lombardy, Italy, who required treatment in the ICU, the median (IQR) age was 63 (56-70) years and 1,304 (82\%) were male. Of the 1,043 patients with available data, 709 (68\%) had at least one comorbidity and 509 (49\%) had hypertension. The second most common comorbidities were CVD [223 patients, 21\% (95\% CI, 19-24)] and hypercholesterolemia [188 patients, $18 \%$ (95\% CI, 16-20\%)]. ICU mortality was higher in those who were older ( $\geq 64$ years). The prevalence of hypertension was higher among patients who died in the ICU (63\%, 195 of 309 patients) compared with those discharged from the ICU (40\%, 84 of 212 patients) [difference, 23\% (95\% CI, 15-32); $P<$ $0.001](17)$. 
Emerging evidence strongly implicates COVID-19 as a vascular disease, with many COVID-19 positive patients purportedly developing cardiovascular complications, such as myocardial injury (18), cardiac arrhythmia (19) and thromboembolism $(20,21)$. Interestingly, cardiovascular complications have also been reported in patients with no underlying pathology, for instance with acute viral myocarditis $(22,23)$. Cardiovascular (CV) system involvement is associated with higher mortality rates and is largely indicated by elevated inflammatory biomarkers, including D-dimer, cardiac troponin (cTn), ferritin, and interleukin (IL)-6 (24). For further insight, readers are directed to our review on Vascular Manifestations of COVID-19 (25) in this series.

\section{Myocardial Damage: The Role of Cardiac Troponin and Other Relevant Markers}

A number of studies show that a high proportion of COVID19 patients exhibit elevated levels of cardiac damage biomarkers, such as cTn, with reports of up to $38 \%$ of patients testing positive for COVID-19 displaying high circulating levels of cTn (26). In comparison to COVID-19 patients with low cTn, those exhibiting high levels of cTn are hospitalized for longer requiring mechanical ventilation and admission to ICU, are at a significantly greater risk of developing ARDS and cardiac arrhythmias, and ultimately have a higher risk of mortality (27). In a study comparing clinical characteristics between survivors of COVID-19, and those who succumbed to the disease, researchers found that elevated levels of cTn were found in $77 \%$ of patients who subsequently died, compared to only $14 \%$ of patients who had survived (28). In addition, Guo et al. (29) showed that myocardial injury (elevated cTnT levels) was associated with worse outcome. Patients with underlying CVD are more likely to present with high cTn levels, with the poor prognosis for those with elevated levels further compounded if the patient had underlying CVD, compared to those without underlying CVD (69.4 vs. $37.5 \%$ mortality rate, respectively) (29). In the study by Zhou et al. (16) the highest OR for mortality in COVID-19 patients $(n=191)$ was for elevated cTn (>28 pg/mL, OR: 80.1) compared to other biomarkers, including circulating lymphocyte count (OR: 0.02) and D-dimer (OR: 20.04). It is also evident that throughout hospitalization, levels of cTn rise, and importantly, survivors showed no rise in this biomarker during the hospital stay, whereas patients with COVID-19 who died from complications, showed a steady upward rise in cTn until death (16). In another study, a significant predictor of mortality due to COVID-19 was the peak cTn during hospitalization, not the level measured upon admission (26), suggestive that risk stratification should include serial cTn measurements.

Besides cTn, other biomarkers, such as creatine kinase (CK), electrocardiographic (ECG) changes, and imaging might also reveal cardiac pathology in COVID-19 patients. Data acquired from multi-centers showed plasma lactate dehydrogenase and CK levels were correlated with COVID-19 severity and ICU admissions, reaching 26.1 and $70.5 \%$, respectively (30). CK
isoenzyme-MB (CK-MB), myohaemoglobin (MYO), and $\mathrm{N}$ terminal pro-brain natriuretic peptide (NT-proBNP) are elevated above normal ranges in $3.7,10.6$, and $12.4 \%$ confirmed cases, respectively (31). When stratified by disease severity, patients with abnormal CK-MB, MYO, and NT-proBNP increased to $6.7,26.7$, and $33.3 \%$ respectively in the critical cases, underscoring underlying ischaemia and cardiac dysfunction. This is further supported by ECG findings characteristic of ischaemia, such as T-wave depression and inversion, ST depression, and presence of Q waves (18). In a case report, the presence of acute pulmonary embolism in COVID-19 was associated with right ventricular dilatation and dyskinesis on echocardiography, indicating that some patients develop ventricular hypertrophy (32).

\section{Immune Response to COVID-19: Healthy vs. Hyperactive}

The immune response to COVID-19 can be split into a healthy antiviral immune response or a defective/overactive immune response. The latter has been linked to damage to the lungs and other organs, resulting in onset of severe illness. Initially, SARS-CoV-2 infection and destruction of lung cells switches on antiviral defenses triggering a local immune response. This includes recruitment of macrophages and monocytes to respond to the infection, interferons and release of cytokines and chemokines and primed adaptive $\mathrm{T}$ and $\mathrm{B}$ cell immune responses. In most cases, this process is capable of resolving the infection. However, in some cases, a dysfunctional immune response occurs, resulting in severe lung and multi-system damage, and possible failure (33).

In the healthy immune response, the innate antiviral defenses fight against the virus and virus-specific $\mathrm{T}$ cells can later eliminate the infected cells before the virus spreads. Neutralizing antibodies in these individuals can block viral infection, and phagocytic cells such as alveolar macrophages recognize neutralized viruses and apoptotic cells and clear them by phagocytosis. Altogether, these processes lead to clearance of the virus with minimal lung and multi-system damage, resulting in recovery (33).

In a defective immune response, there is a hyperactivation of the immune cells, with excessive infiltration of monocytes, macrophages and $\mathrm{T}$ cells, in the lungs. This causes overproduction of pro-inflammatory cytokines, the so-called "cytokine storm" or "cytokine release syndrome," which eventually can lead to lung damage, pulmonary oedema and pneumonia. The resulting cytokine storm leads to widespread inflammation circulating to other organs, leading to multiple organ damage (33). Elucidating the mechanisms underlying the immune response to COVID-19 and the causes for the hyperactivation of the immune response are at the forefront of this exciting research area. Recently, Merad and Martin (34) reviewed how activated monocyte-derived macrophages leading to a dysregulated macrophage response contribute to the COVID-19 cytokine storm by releasing massive amounts of pro-inflammatory cytokines (34). Moreover, the biological and clinical consequences of the so-called cytokine storm are still largely unknown. 


\section{CYTOKINE STORM IN COVID-19}

The term cytokine storm was first employed in describing the events modulating the onset of graft-vs.-host disease (35). Cytokine storms characterize a wide spectrum of infectious and non-infectious diseases. Since 2005, it was associated to the avian H5N1 influenza virus infection (36) and then infections with MERS and SARS, with an inflammatory milieu containing IL-1 $\beta$, IL-6, and TNF- $\alpha$ being associated with worse disease outcomes (37). Now, severe COVID-19 disease caused by SARS-CoV-2 infection is also associated with a dysregulated and hyperactive systemic inflammatory response; a cytokine storm (38).

It was first reported that several pro-inflammatory cytokines and chemokines, including IL-2, IL-7, IL-10, CXCL10 (IP-10), CXCL8, CCL2 (MCP1), TNF $\alpha$, and IFN $\gamma$ were higher in the plasma of COVID-19 patients as compared to healthy controls. More importantly, among infected patients, IL-2, IL-7, IL-10, granulocyte colony- stimulating factor (G-CSF), macrophage inflammatory protein $1 \alpha(\mathrm{MIP} 1 \alpha)$, CXCL10, CCL2, and TNF $\alpha$ circulating concentrations (but not those of IFN $\gamma$ ) were found to be significantly higher in patients requiring admission to ICU and mechanical ventilation, compared to patients experiencing a less severe clinical course (11).

Chen et al. (39) characterized the immunological features of COVID-19 patients presenting with differing disease severity. Eleven patients with severe disease displayed significantly higher serum levels of IL-6, IL-10, and TNF- $\alpha$ and lower absolute numbers of $\mathrm{T}$ lymphocytes, $\mathrm{CD} 4^{+} \mathrm{T}$ cells, and $\mathrm{CD} 8^{+} \mathrm{T}$ cells as compared with 10 patients with moderate disease. Of note, severe cases were characterized by a lower expression of IFN- $\gamma$ by $\mathrm{CD} 4^{+} \mathrm{T}$ cells as compared with moderate cases (39). Likewise, analysis from Liu et al. (40) demonstrated significant decreases in the counts of T cells, especially $\mathrm{CD} 8^{+} \mathrm{T}$ cells, as well as increases in IL-6, IL-10, IL-2, and IFN- $\gamma$ levels in the peripheral blood in the severe COVID-19 cases $(n=13)$ compared to those in the mild cases $(n=27)$, suggesting that disease severity is associated with significant lymphopenia and hyperinflammation.

Del Valle et al. (41) used a multiplex cytokine assay to measure serum IL-6, IL-8, TNF- $\alpha$, and IL-1 $\beta$ in hospitalized COVID19 patients $(n=1,484)$ upon admission to the Mount Sinai Health System in New York, USA. They showed that serum IL-6, IL-8, and TNF $\alpha$ levels at the time of hospitalization were strong and independent predictors of patient outcomes, with elevated inflammatory profile associated with reduced survival. Importantly, when adjusting for disease severity score, common laboratory inflammation markers, hypoxia and other vitals, demographics, and a range of comorbidities, IL- 6 and TNF- $\alpha$ serum levels remained independent and significant predictors of disease severity and death (41).

In an elegant study, Lucas et al. (42) have identified that development of a maladaptive immune response profile was associated with severe COVID-19 outcome, and early immune signatures correlated with divergent disease trajectories. Through serially analyzing immune responses in peripheral blood in 113 COVID-19 patients with moderate (non-ICU) and severe (ICU) disease, they revealed an association between early, elevated cytokines and worse disease outcomes. Indeed, they observed a "core COVID-19 signature" shared by both moderate and severe groups of patients defined by the following inflammatory cytokines that positively correlated with each other; these included: IL-1 $\alpha$, IL-1 $\beta$, IL-17A, IL-12 p70, and IFN- $\alpha$. In severe patients, they observed an additional inflammatory cluster defined by: thyroid peroxidase (TPO), IL-33, IL-16, IL-21, IL23 , IFN- $\lambda$, eotaxin, and eotaxin 3. Interestingly, most of the cytokines linked to cytokine release syndrome, such as IL$1 \alpha$, IL-1 $\beta$, IL-6, IL-10, IL-18, and TNF- $\alpha$, showed increased positive associations in severe patients. After day 10, in patients with moderate disease, these markers steadily declined. In contrast, severe patients maintained elevated levels of these core signature makers. Notably, additional correlations between cytokines emerged in patients with severe disease following day 10. Therefore, there were sharp differences in the expression of inflammatory markers along disease progression between patients who exhibit moderate vs. severe COVID-19 symptoms. Altogether, data showed a broad elevation of type-1, type2 , and type- 3 signatures in severe cases of COVID-19, with distinct temporal dynamics and quantities between severe and moderate patients. Unsupervised clustering analysis of plasma and peripheral blood leukocyte data identified four immune signatures, representing (A) tissue repair growth factors, (B) type- $2 / 3$ cytokines, (C) mixed type- $1 / 2 / 3$ cytokines, and (D) chemokines involved in leukocyte trafficking that correlated with three distinct disease trajectories of patients. The immune profile of patients who recovered with moderate disease was enriched in tissue reparative growth factor signature (A), while the profile for those with worsened disease trajectory had elevated levels of all four signatures. Overall, results suggested that a multi-faceted inflammatory response is associated with late COVID-19 severity, which raises the possibility that early immunological interventions that target inflammatory markers predictive of worse disease outcome are preferred to blocking late-appearing cytokines.

Supporting the work of Lucas et al. (42) a recently published article has identified a core peripheral blood immune signature across 63 hospital-treated patients in London, UK with COVID19. Specifically, among several changes in immune cells expressed at unusual levels in the blood of patients, the work identified a triad of IP-10 (CXCL10), IL-10, and IL-6 to correlate strongly with disease severity. Indeed, patients with COVID-19 who displayed measurably higher levels of IP-10 (CXCL10), IL-10, and IL-6 when first admitted to hospital went on to become more severely ill. The triad of cytokines was found to be a rigorous predictor of disease severity than commonly-used clinical indicators, including CRP, D-dimer, and ferritin (43).

As the COVID-19 cytokine storm is a multi-faceted inflammatory response, therapies that target this as a whole and those that enhance tissue repair (i.e., mesenchymal stem/stromal cells; MSCs) should be considered. Indeed, Lucas et al. (42) found IL-6 to be highly enriched in patients with severe disease. In fact, all ICU patients in their study, including the ones who succumbed to the disease, received Tocilizumab, an IL-6R blocking antibody. Positive outcomes have been reported with Tocilizumab treatment, including a reduction in an inflammatory-monocyte population associated with worse 
outcomes (44). However, as patients still succumbed to COVID19, this highlights the need for combination therapy to block other cytokines highly represented in severe COVID-19 cases, including inflammasome-dependent cytokines and type- 2 cytokines (42).

\section{THE EFFECTS OF THE COVID-19 CYTOKINE STORM}

\section{On the Lungs Leading to Acute Respiratory Distress Syndrome (ARDS)}

Acute respiratory distress syndrome (ARDS) is a form of hypoxaemic respiratory failure that is characterized by severe impairment of gas exchange and lung mechanics, with a high case fatality rate. Acute respiratory distress syndrome can come about through the severe widespread inflammatory injury present throughout the lungs, leading to a loss of vascular barrier integrity and likely promoting pulmonary oedema, thereby causing inflammation of endothelial cells (endothelialitis). Acute respiratory distress syndrome is a prominent feature in patients with severe COVID-19 infection $(45,46)$ and is the leading cause of mortality (47).

The precise pathophysiological mechanisms underlying ARDS in COVID-19 patients are not fully understood. However, alveolar macrophages are central to mediating the inflammation associated with ARDS (48), with the initial inflammatory stage involving alveolar macrophages interacting with lymphocytes (49) and epithelial cells (50), thereby augmenting the inflammatory response and accentuating tissue damage (51). Following initial stimulation, neutrophils and circulating macrophages are recruited to the lungs (activated by the pro-inflammatory cytokines), thereby triggering further inflammatory responses (52) equating to a positive feedback loop. These cells may disrupt the air-blood barrier by causing collateral tissue damage, particularly to airway epithelial cells and vascular endothelial cells, which express the ACE2 entry receptor for SARS-CoV-2; the damage of vascular endothelial cells may account for thrombotic microangiopathies (53). Furthermore, severe infection of the lung alveoli allows the SARS-CoV-2 virus and pro-inflammatory cytokine overload to enter the systemic circulation where it can infiltrate multiple organs, particularly since cells in many of them co-express ACE2 and TMPRSS2 $(7,8,54)$.

In addition to the marked lung damage observed in COVID19 infection, clinical cohort studies have revealed involvement of the kidneys $(11,16,19,30,55,56)$, liver $(11,30,57,58)$, gastrointestinal tract $(11,30,59,60)$, central nervous system $(61,62)$, and CV system $(16,18,19,63)$.

\section{Mitochondrial-Related Mechanisms}

Mitochondria are essential for meeting the rise in energy demand required to fuel the immune system response and also for inducing immunomodulatory mechanisms, serving as a platform for host defense against RNA viruses such as SARS-CoV-2 (64, 65). The effects of SARS-CoV-2 infection upon mitochondrial respiratory capacity is a key consideration in the context of the host cytokine response. Mitochondrial respiratory capacity has been suggested to account for $10-30 \%$ of the variance in circulating leukocyte immune reaction across individuals, influencing the cytokine signature produced by leukocytes in response to lipopolysaccharide (LPS) administration (66). In particular, complex IV activity was positively correlated with LPS-stimulated IL-6 release (66). This is of particular interest in relation to SARS-CoV-2, whereby blood IL- 6 has been identified as a predictor of patient fatality (47).

Aside from respiration, mitochondria are essential in host cell detection of RNA via pattern recognition receptors (PPRs), including cytosolic sensors retinoic acid-inducible gene 1 (RIG1) and melanoma differentiation-associated protein 5 (MDA5) (67). These utilize the mitochondrial signaling protein MAVS (mitochondrial antiviral signaling protein), which recruits the E3 ligases TNF receptor associated factor 3 (TRAF3) and TRAF6, facilitating activation of interferon regulatory factors (IRFs) and NF- $\mathrm{B}$ to induce antiviral genes. In this manner, MAVS activity coordinates the activation of a dominant antiviral mechanism, the type 1 interferon (IFN) pathway (64). SARS$\mathrm{CoV}-2$ open reading frame (Orf) $9 \mathrm{~b}$ targets the translocase of outer mitochondrial membrane protein 70 (TOMM70), linking mitochondrial signaling to induction of the IFN pathway (68). The Orf9b of SARS-CoV-2 also localizes to the outer mitochondrial membrane, disrupting the MAVS signalosome (69) and impairing the host IFN response $(69,70)$. Other mitochondrial factors that may impact the IFN response include mitochondrial stress, whereby release of mtDNA into the cytosol is detected by the DNA sensor cGAS, which promotes STINGIRF3 signaling, potentiating IFN pathway signaling (71).

Inflammasomes, the multiprotein complexes providing a platform for the activation of pro-inflammatory caspase1 culminating in cytokine release, are also mitochondrialdependent. An example is NLRX1, a target of SARS-CoV-2 Orf9c (68). NLRX1 interacts with mitochondrial complex III, stimulating reactive oxygen species (ROS) production (72). ROS production from mitochondrial complexes I and III is known to mediate both innate and adaptive viral immune responses (73), impacting both MAVS and NF- $\kappa$ B signaling (72).

Pro-inflammatory cytokines are known to elicit metabolic alterations, with NF- $\mathrm{B}$ and interleukin signaling impacting glucose control and glycolytic function. For instance, development of insulin resistance has been linked to IL-1 and IL- 6 signaling in the context of type 2 diabetes mellitus (74). This is a key consideration in SARS-CoV-2, whereby poor blood glucose control has been associated with higher mortality in diabetic patients (75) and high glucose levels associated with viral replication in monocytes, with enhanced glycolytic capacity coinciding with raised IL-1 $\beta$ (76).

NF- $\kappa \mathrm{B}$ mediated metabolic re-programming has been demonstrated in acute viral myocarditis (VM) (77, 78), a condition characterized by viral induced leukocyte infiltration and cardiac dysfunction. Case studies of acute VM have been reported in female COVID-19 patients (ages 21 and 43), resulting in substantial disruption to cardiac function in the absence of coronary artery disease $(22,23)$. Viral fulminant myocarditis, a syndrome on the clinical spectrum of acute myocarditis, has also 
been associated with death in SARS-CoV-2 patients suffering from cardiac injury (79).

In human and mouse models of VM, cardiac inflammation indicated through cytokine mediated NF- $\mathrm{KB}$ activation was linked to impaired expression of genes related to oxidative metabolism. This included downregulation of genes encoding mitochondrial regulatory proteins associated with biogenesis (PGC-1 $\alpha$, PGC1-1 $\beta$, Tfam, and NRF-1) alongside regulators of $\beta$-oxidation (e.g., PPAR- $\alpha$ ), tricarboxylic acid cycle and electron transport chain (ETC) function. This coincided with a fall in high energy phosphates and NAD levels and a shift toward anaerobic glycolysis, indicated through increased expression of glucose and lactate transporters and glycolytic enzymes (77). Together, this indicates that the inflammatory response associated with acute VM initiates reprogramming of cardiomyocyte energy metabolism away from oxidative metabolism and toward glycolysis. This culminated in an energy-starved status of the heart, the extent to which likely contributed to impaired cardiac function. NF- $\mathrm{KB}$ signaling has also been linked to impaired insulin signaling by stimulating phosphorylation of insulin receptor substrate-1, in turn inducing insulin resistance and cardiac dysfunction associated with VM (78). The metabolic implications of VM onset and resulting impairment of myocardial function are thus vital considerations in the pathophysiology of SARS-CoV-2 infection.

\section{On the Cardiovascular System}

A number of case reports have demonstrated cardiac abnormalities in patients with COVID-19, including myocarditis, myo-pericarditis, electrocardiographic complications, cardiogenic shock, decompensated heart failure, and other histological/imaging complications, such as reduced left ventricular ejection fraction (LVEF) (80-85). Moreover, and as described previously, cross-sectional studies have consistently reported elevations in cardiac injury markers, such as $\mathrm{cTn}$, NT-proBNP, and creatine kinase myocardial band (CK-MB) concentrations, with patients presenting with cardiac injury being at a higher risk of mortality, even after being adjusted for confounding variables such as age, pre-existing CVD, and ARDS (18). These data give strong evidence for cardiac complications associated with COVID-19, however, the mechanisms for these complications may not be solely the result of a direct viral infection of cardiac cells.

The CV system is also at high-risk as a result of indirect mechanisms, such as the cytokine storm. The cytokine storm is likely to induce cardiovascular damage through mechanisms related to endothelial dysfunction, atherosclerotic plaque instability/rupture, cardiomyocyte death, and myocarditis. The mechanisms of endothelial dysfunction within the COVID-19 population are not limited to elevations in pro-inflammatory cytokine concentrations and include direct viral infection of endothelial cells, angiotensin II (Ang II) hyperactivity, complement activation, and other elements of immune dysregulation, such as neutrophil extracellular trap (NET) formation. Indeed, evidence of SARS-CoV-2 viral structures have been observed in endothelial cells in various tissue beds (63), which may promote an imbalance between ACE2 and
Ang II. Liu et al. (86) support this notion by demonstrating elevated plasma Ang II concentrations in patients with COVID19. For a more in depth review of direct viral infection of endothelial cells, including Ang II hyperactivity, readers are directed to our recent review on the vascular manifestations of COVID-19 (25). Complement activation has been associated with microthrombosis in a small number of patients with COVID-19 (87) and NET formation has been correlated with COVID-19-associated ARDS (88). Both complement activation and NET formation are associated with pro-inflammatory responses. The complement system detects viral pathogens, thus contributing to the innate immune response to viral infections (89), whilst NETs have the ability to induce IL- $1 \beta$ secretion from macrophages and play a role in the development of atherosclerosis, causing endothelial damage and dysfunction (90, 91). Moreover, endothelial cells undergoing apoptosis have been shown to activate the complement system (92), which may further exacerbate cytokine secretion and promote microthrombosis. Therefore, it should be acknowledged that direct viral infection of endothelial cells, subsequent Ang II hyperactivity and the pro-inflammatory effects of complement activation and NET formation promote both direct and indirect perturbations to the cardiovascular system, whilst exacerbating the cytokine storm. Moving forward, the predominant focus of this section is to discuss the potential effects of the cytokine storm upon the cardiovascular system.

The cytokine storm is not only one of the predominant pathophysiological mechanisms of fulminant myocarditis (without evidence of viral infiltration) (93), which has been reported in patients with COVID-19, but inflammatory infiltration into endothelial cells has also been reported in histological studies $(63,94)$. Inflammatory infiltration into endothelial cells promotes endothelialitis, perturbing endothelial cell membrane function, loosening inter-endothelial junctions, and causing cell swelling $(94,95)$. Indeed, Varga et al. (63) showed endothelial cell death and dysfunction in patients infected with SARS-CoV-2, which facilitated the induction of endothelialitis in several organs, including cardiac tissue, as a direct consequence of viral involvement and of the host inflammatory response.

The presence of endothelialitis demonstrates the activation of endothelial cells, promoting the expression of cell-surface adhesion molecules and thus the binding of inflammatory cells to the endothelium $(96,97)$. These pathophysiological consequences promote vascular hyperpermeability. Disruption of inter-endothelial junctions cause endothelial cells to be "pulled apart," thus resulting in inter-endothelial gaps $(95,98)$, denoting cytoskeletal alterations to the endothelium. Moreover, this cytokine storm-induced endothelial dysfunction pre-disposes the $\mathrm{CV}$ system to a pro-coagulant state, promoting thromboembolic events, which has been linked to higher disease severity, and higher instances of mortality (99). Interestingly thrombin exposure, coupled with an elevation in the influx of $\mathrm{Ca}^{2+}$ promotes elevations in endothelial cell permeability which can be induced by an increase in TNF- $\alpha$ expression $(100,101)$.

Elevations in cytosolic $\mathrm{Ca}^{2+}$ influx into endothelial cells is a pivotal step in the disruption to inter-endothelial junctions and thus the progression to increased vascular permeability 
(101, 102). A determinant of this increased $\mathrm{Ca}^{2+}$ influx is the upregulation of transient receptor potential channels, which is induced via TNF- $\alpha$ (100), causing a destabilization of microtubules (103). Evidence supports the notion of a cytokine-induced hyperpermeability response of the vasculature, with Tinsley et al. (104) demonstrating the role of cytokine (TNF- $\alpha$, IL-1 $\beta$, and IL-6) induced-vascular hyperpermeability through a protein kinase $\mathrm{C}$ (PKC) and myosin light chain kinase (MLCK) dependent mechanism in cultured rat heart microvascular endothelial cells. Moreover, the authors replicated these findings in vivo using a coronary ischemia/reperfusion (I/R) rodent model of heart failure, demonstrating TNF- $\alpha$ increases endothelial permeability in a PKC and MLCK dependent manner (104). Therefore, translating this to COVID-19 pathophysiology, cytokine storm induced $\mathrm{Ca}^{2+}$ influx into endothelial cells may be a contributing mechanism underpinning the disruption to inter-endothelial junctions and the promotion of vascular permeability. Furthermore, the cytokine-induced stimulation of PKC and MLCK may promote direct damage to cardiac tissue, which may pose significant deleterious effects upon patients with pre-existing CVD, a common comorbidity in the more severe COVID-19 population (105).

Histological studies in pulmonary vasculature have indicated endothelialitis, with unexpected observations of intussuseptive angiogenesis. In this study (94), the degree of intussuseptive angiogenesis was associated with the duration of hospitalization. Whilst hypoxia may be a contributing mechanism, the authors concluded the predominant mechanism was likely the presence of endothelialitis and thrombosis (94). Intussuseptive angiogenesis is the formation of intravascular vessel formation, through non-sprouting mechanisms, commonly observed as "pillar" formation within the vasculature (106), which can significantly alter the microcirculation, and can be triggered by extraluminal processes, including inflammation (107). Inflammatory-mediated intussuseptive angiogenesis has been demonstrated previously in murine models of colitis, suggesting this is an adaptive response to prolonged inflammation (108). This provides further evidence of the perturbations to the vasculature caused by the cytokine storm in COVID-19. The promotion of intussuseptive angiogenesis as an adaptive response to vascular damage, has also been shown to accelerate fibrotic neovascularisation (109).

Inflammatory environments also promote the generation of ROS which can result in damage and dysfunction of the vasculature. ROS act as signaling molecules to defend against oxidative stress by promoting the upregulation of antioxidant mechanisms, however, high concentrations of ROS can activate endothelial cells and inhibit normal endothelial functioning. Cytokines, such as TNF- $\alpha$, have been shown to interact with the ETC and stimulate the release of mitochondrialderived ROS, such as hydrogen peroxide (110) and superoxide (111). Moreover, in response to infections, inflammatory cytokines, such as TNF- $\alpha$ and IL- $1 \beta$, coming into contact with endothelial cells induce $\mathrm{NAD}(\mathrm{P}) \mathrm{H}$ oxidase-derived ROS (112, 113). The generation of excessive ROS elevates superoxide anion production, which can degrade nitric oxide (NO), lead to the formation of other free radicals, such as peroxynitrite, and thus result in endothelial cell dysfunction and apoptosis $(96,114,115)$. Therefore, it is likely that the cytokine storm experienced in patients with COVID-19 will promote the elevation in ROS and result in oxidative stress, which is a key mechanism of endothelial dysfunction in hypertension (116) and CVD (117). Elevations in ROS also act as secondary inflammatory signals, which has been shown to induce the secretion of pro-inflammatory cytokines, such as IL-1 $\beta$, TNF- $\alpha$, and IL-6 (118). Therefore, this creates a vicious cycle of cytokine-induced oxidative stress and ROSinduced pro-inflammatory cytokine signaling, secondary to the COVID-19 hyper-activation of the immune response.

Inflammatory cytokines do not just alter endothelial structure and function. Cytokines such as TNF- $\alpha$, IL-1 $\beta$, and IL-6 promote vascular smooth muscle cell (VSMC) proliferation from the media to the intima of the vasculature, which results in the secretion of extracellular matrix proteins within, and thus expanding the intima in pathological conditions, such as atherosclerosis (119). Moreover, in human coronary VSMCs, IL-1 $\beta$ has been shown to stimulate an upregulation in Rhokinase, via a PKC-dependent mechanism, which may contribute to medial thickening and the atherogenic environment (120). Interestingly, this can also be stimulated by an upregulation in angiotensin II, which has been noted within the COVID19 literature if infected cells experience a downregulation of ACE2 expression (121), which will also contribute to the pro-inflammatory environment experienced in patients with COVID-19. Activation of RhoA can also be stimulated by TNF- $\alpha$ which has been shown to promote endothelial cell permeability in cultured human umbilical vein endothelial cells (HUVECs) (122). These pathophysiological processes are shared with thrombosis, which is a common manifestation in patients with severe COVID-19 (99). Combined with damage to endothelial cells contributing to the apparent "COVID-19 coagulopathy" (123), VSMC proliferation, stimulated by various cytokines, may contribute to the high instance of coagulation derangements and thromboembolic events observed in patients with severe COVID-19.

Whilst the COVID-19 induced cytokine storm can predispose the CV system to damage and progression of pre-existing cardiovascular comorbidities, perturbations to vascular cells may also contribute to the overexpression of pro-inflammatory cytokines. Both endothelial cells and VSMCs secrete proinflammatory cytokines when either damaged or undergoing apoptosis. Expression of cell-surface adhesion molecules and certain cytokines, such as IL-8, on the surface of endothelial cells induce a pro-inflammatory phenotype and the recruitment of blood monocytes which induce the secretion of proinflammatory cytokines, such as TNF- $\alpha$ and IL-1 $\beta$ (124). Moreover, under atherogenic conditions, VSMCs have been shown to also adopt a pro-inflammatory phenotype, promoting the secretion of IL- 6 and IL-8, along with cell-surface adhesion molecules, such as vascular cell adhesion molecule $1(124,125)$. Therefore, both endothelial cells and VSMCs, once damaged, may switch to a pro-inflammatory phenotype and thus propagate the expression of pro-inflammatory cytokines.

Whilst there is a plethora of evidence which suggests that the cytokine storm experienced in COVID-19 patients may promote 
damage to the vasculature, sustained inflammation directly contributes to progressive cardiomyocyte apoptosis. Elevated TNF- $\alpha$ levels seen in a variety of clinical conditions including COVID-19, drives cardiomyocytes to apoptosis $(126,127)$. TNF$\alpha$ can induce cardiomyocyte apoptosis directly, via the TNF receptor, or indirectly, through stimulation of NO production or ROS, which in turn is induced by pro-inflammatory cytokines such as IL-1, IL-6, TNF- $\alpha$, and IFN-7 (128). High levels of cTn are reflective of cardiomyocyte death and injury, and as stated earlier, are associated with COVID-19 disease severity and mortality (16).

In the heart, the acute inflammatory response can expand tissue damage and prolonged inflammation leads to accentuated adverse remodeling. Indeed, pro-inflammatory cytokines and upregulated monocytes/macrophages can inhibit cardiac repair, which is dependent on timely suppression and resolution of pro-inflammatory signaling. Activation of IL-1 signaling induces cytokine expression, promotes matrix-degrading properties, suppresses fibroblast proliferation and inhibits transdifferentiation of fibroblasts into myofibroblasts, altogether delaying activation of a reparative response (129). Moreover, a severe or prolonged reparative response is associated with pathological scarring and fibrosis (130).

The full extent of cardiovascular cell dysfunction and death, induced by the cytokine storm in COVID-19, is yet to be fully elucidated. This section provides evidence of the potential effects and mechanisms of the COVID-19 cytokine storm on the cardiovascular system. It is likely that cardiomyocyte and vascular cell damage and dysfunction, as well as mitochondrialrelated mechanisms play a role in the progression of COVID19 and in the pathogenesis of cardiovascular injury in COVID19. The induction of ROS generation and the ensuing oxidative stress, coupled with vascular cell secretion of pro-inflammatory cytokines further propagates the inflammatory environment and exaggerated immune response in patients with COVID19 , promoting disease progression and multi-organ dysfunction. Moreover, cardiac and vascular cell dysfunction pre-disposes the $\mathrm{CV}$ system to a pro-inflammatory and pro-atherogenic state and thus increases the risk of serious cardiac events. Therefore, suppression of the cytokine storm, is key for improving patient outcomes with COVID-19, whilst also protecting the CV system. One such therapy is transplantation of mesenchymal stem/stromal cells (MSCs).

\section{MSCs AS A THERAPY FOR SEVERE COVID-19 PATIENTS}

\section{Immunomodulatory Role of MSCs}

An important function of MSCs is that they have powerful immunomodulatory properties, possessing natural abilities to detect changes in their environment such as inflammation. Mesenchymal stromal cells can both directly and indirectly stimulate immunomodulation by interacting with immune cells and releasing various anti-inflammatory cytokines via paracrine effects, respectively (131). Functional alterations to dendritic cells, monocytes, macrophages, regulatory $\mathrm{T}$-cells
(Tregs), and B-cells underpin MSCs' immunomodulatory capacity, whilst also through cell-to-cell interaction mechanisms (13). Once systemically administered, a significant portion of MSCs accumulate within the lungs, which can promote anti-inflammatory effects, thus improving the lung microenvironment and potentially restoring vascular barrier integrity and reducing oedema; whilst also promoting endogenous repair and regeneration mechanisms to reduce (or prevent further) fibrosis of the lung $(132,133)$.

Animal models of ARDS lung injury due to influenza virus have shown that infection by this and related viruses causes ion channel transporter abnormalities which causes fluid secretion, a major cause of the pulmonary oedema in the lungs of infected individuals. In such animal models, MSCs prevent or reduce the secretory effect of influenza virus on lung alveolar cell ion channels, and when administered intravenously in aged animals have resulted in increased oxygenation, improved respiration, reduction in pro-inflammatory cytokines, and an increase in survival (134).

Mesenchymal stromal cells are well-known to respond to the inflammatory environment with multimodal activity resulting in sustained anti-inflammatory effects; conversion of Th17 cells to anti-inflammatory FOXP3 Treg cells by MSC-secreted transforming growth factor (TGF) $\beta 1$ and the essential presence of CCL18 producing type-2 anti-inflammatory macrophages from differentiated pro-inflammatory monocytes (135). They are known to dampen the innate immune response to insult (such as acute lung injury, burn injuries) or infection via preventing neutrophil infiltration into injured/infected sites (136-139) or via shifting the phenotype of macrophages from an M1 to M2 antiinflammatory phenotype (140). Specifically the MSCs appear to reduce inflammation via reducing macrophage secretion of neutrophil chemoattractant proteins CXCL1, CXCL2 $(137,141)$ as a result of activation of phosphorylation of p38 MAPK (141) and greater IL-10 release (137), dampened production of IL-6 and TNF- $\alpha(137,138)$, and suppression of reactive oxygen species production by neutrophils $(142,143)$. Together this contributes toward a shift from a pro- to an anti-inflammatory environment and is an essential part of the immunomodulatory function of MSCs as this helps prevent against autoimmunity (13), as demonstrated in MSC-treated graft vs. host disease (144).

Mesenchymal stromal cells can also induce local and systemic immunomodulatory responses independently of the cytokine storm. For instance, MSCs can prevent the infiltration of cells of the innate immune system, thereby indirectly reducing the secretion of inflammatory cytokines. In a murine model, BM-MSCs reduced $\mathrm{CD}_{4} 5^{+}$cells and neutrophil populations in the mucosa via release of tumor necrosis factor-induced protein 6 (TSG-6) (145). Both MSCs and TSG-6 induced the expansion of regulatory macrophages, expressing IL-10 and inducible nitric oxide synthase (NOS), and increased the population of $\mathrm{FOXP}_{3} \mathrm{CD} 45^{+}$cells. Interestingly, TSG-6 was associated with MSC-mediated depletion of corneal, splenic, and peripheral blood $\mathrm{CD}_{11 \mathrm{~b}^{+}}$monocytes/macrophages in a model of inflammatory corneal neovascularization (146). In addition to TSG-6, MSCs can also release other bioactive molecules that promote protective responses in innate immune 
cells, including kynurenic acid (147), spermine (148, 149), and lactate (150). Adaptive immune cells, such as T and B cells, are also direct targets of MSCs. Following transplantation, MSCs form aggregates with $\mathrm{B}$ and $\mathrm{T}$ cells, stimulating the production of FOXP3 and IL-10 (145). Mesenchymal stromal cells directly inhibit the activation of cytotoxic $\mathrm{CD}^{+} \mathrm{T}$ cells via downregulation of CD25, CD38, and CD69 (151). In B cells, MSCs downregulate chemotactic properties, with no effect on costimulatory molecules or cytokine production (152). Mesenchymal stromal cell-mediated indoleamine 2,3dioxygenase signaling promotes the survival and proliferation of $\mathrm{CD}^{+}$Bregs (153). There are also data to suggest that MSCs could act via extracellular vesicles and exosomes to modulate innate and adaptive immunity $(154,155)$. The immunoregulatory mechanisms of mesenchymal stem and stromal cells in inflammatory disease are reviewed in (156).

Consequently, on the basis of these and other studies with MSCs in animal models, clinical investigators have postulated that human MSCs should be effective in the pathology of human ARDS (157). Indeed in a report of allogeneic MSCs in ARDS patients, a single low dose of cells ( 2 million cells/kg/BW) achieved rapid reduction in inflammatory cytokines and efficacy in influenza-related ARDS which was otherwise refractory to conventional supportive therapy (158). For further insight on the therapeutic potential of cell therapy to treat ARDS readers are directed too $(159,160)$.

The systemic redistribution of MSCs have the ability to target other organs that are damaged. As multi-organ damage is a common manifestation in patients with severe COVID-19, this makes MSCs an attractive therapy to combat not only lung damage, but also damage observed in other organs, such as the heart. Therefore, the use of MSCs to modulate the immune response, avoiding, preventing or attenuating the cytokine storm leading to multi-organ failure may be the key for the treatment of COVID-19 infected patients.

\section{Use of MSCs to Treat COVID-19}

Table 1 summarizes the published clinical studies thus far using MSCs as a therapy to treat COVID-19. Table 2 summarizes the ongoing, registered clinical trials using MSCs as a therapy to treat COVID-19. For review articles on the rationale and treatment of COVID-19-related ARDS using MSCs, readers are directed to Moll et al. (165) and Can and Coskun (166).

The first clinical study undertaken in China, showed that for seven patients with COVID-19-related pneumonia, transplantation of $1 \times 10^{6} \mathrm{MSCs} / \mathrm{Kg} / \mathrm{BW}$ allogeneic MSCs was effective by restoring the balance of the immune system resulting in significant resolution of signs and symptoms of pulmonary disease (133). Before the transplantation, all patients had COVID-19-related pneumonia with symptoms of high fever, weakness, shortness of breath, and low oxygen saturation. Results showed that all symptoms had disappeared by 2-4 days after the transplantation. The oxygen saturations rose to $\geq 95 \%$ at rest, without or with oxygen treatment. This was not the case in the three placebo control patients. Among the MSC-treated patients, one severe and two mild patients were able to make a recovery and be discharged 10 days after treatment. The study found improvement was particularly dramatic for an elderly male patient in a severe critical condition (133). The improved recovery time with MSC treatment would lead to decreased hospitalization which would be vital for overwhelmed hospital wards and ICUs.

The transplanted MSCs significantly elevated IL-10 and reduced TNF- $\alpha$ concentrations in seven MSC transplanted patients with COVID-19-pneumonia compared to the three patients in the placebo control group receiving standard care. In the severe $(n=4)$ and critically severe $(n=1)$ patients, a significant elevation in Tregs and dendritic cells were observed after MSC administration, compared with the mild and control patients. Specifically, there was a switch from pro-inflammatory cytokine producing $\mathrm{CXCR}^{+} \mathrm{CD} 4^{+} \mathrm{T}$ cells, $\mathrm{CXCR}^{+} \mathrm{CD} 8^{+}$ $\mathrm{T}$ cells, and $\mathrm{CXCR}^{+} \mathrm{NK}$ cells to $\mathrm{CD}^{+} 4^{+} \mathrm{CD} 11 \mathrm{c}^{+} \mathrm{CD} 11 \mathrm{~b}$ mid regulatory dendritic cell (DCreg) population, indicating improvement in immunomodulatory function. Furthermore, in the critically severe patient an over activation of T-cells and natural killer (NK) cells were evident, however, after MSC treatment, T-cells and NK cells were almost eradicated, with the $\mathrm{CD} 14+\mathrm{CD} 11 \mathrm{c}+\mathrm{CD} 11 \mathrm{~b}$ mid DCregs restored to normal levels (133). These findings demonstrate the ability of MSCs to induce their immunomodulatory benefits in a set of patients with COVID-19, restoring the balance of the immune response by attenuating the cytokine storm.

These findings have been further supported within the literature with a case study by Zhang et al. (162) demonstrating a regression of COVID-19 symptoms between 2 and 7 days post-Wharton's Jelly derived human umbilical cord MSCs administration, with a reduction in ground glass opacity and pneumonia infiltration within the lungs 6 days posttransplantation. Moreover, $\mathrm{CD}^{+}, \mathrm{CD}^{+}$, and $\mathrm{CD}^{+}$T-cells were increased and CRP, IL- 6 , and TNF- $\alpha$ concentrations were reduced. Another case report of a patient with severe COVID19 who experienced two cytokine storms, was treated with a synergistic use of convalescent plasma and umbilical cord MSCs. Treatment resulted in lymphocyte counts returning to normal after the fourth day following convalescent plasma administration and a reduction in inflammatory markers, with a steady elevation in $\mathrm{PaO}_{2}$ following the administration of umbilical cord MSCs (167).

One limitation to MSC therapies for treating COVID19 may be the expression of ACE2 and the predominant serine protease responsible for priming the SARS-CoV-2 spike glycoprotein, TMPRSS2, which may promote SARSCoV-2 infection of transplanted cells and thus promote further spread and progression of COVID-19. However, Leng et al. (133) after performing 10x single cell RNA sequencing analysis, demonstrated transplanted MSCs are ACE2-negative and TMPRSS2-negative.

Taken together, via their immunomodulatory and reparative role these studies provide support to the rationale for MSC transplantation as a therapy to treat COVID-19. Moreover, whilst these studies demonstrate evidence for their use against lung damage, the suppression of pro-inflammatory markers will provide protection against damage or further damage to other organs. For example, with COVID-19 leading 
TABLE 1 | Summarisation of clinical studies and ongoing clinical trials assessing the therapeutic benefit of MSC transplantation in patients with COVID-19, including studies assessing the therapeutic potential of MSCs in patients with acute respiratory distress syndrome (ARDS), without COVID-19.

\begin{tabular}{|c|c|c|c|c|c|c|}
\hline Citation & $N$ & Subjects & $\begin{array}{l}\text { MSC source and } \\
\text { dose }\end{array}$ & MSC timing & Recipient site & Results \\
\hline Leng et al. (133) & $\begin{array}{l}\text { MSC transplant: } \\
n=7 ; \mathrm{CON}: n=3\end{array}$ & COVID-19 pneumonia & $\begin{array}{l}\text { Clinical grade ACE2- } \\
\text { MSCs at } 1 \times 10^{6} \\
\text { cells } / \mathrm{kg}\end{array}$ & $\begin{array}{l}\text { The time when symptoms } \\
\text { and/or signs were still getting } \\
\text { worse, even as the expectant } \\
\text { treatments were being } \\
\text { conducted }\end{array}$ & Systemic & $\begin{array}{l}-\uparrow I L-10 \text { vs. CON } \\
-\downarrow \text { TNF- } \alpha \text { vs. CON } \\
-\leftrightarrow \text { IP-10 } \\
\text { - Trend for } \uparrow \text { VEGF vs. CON } \\
\text { - Inflammation, AAT, MYO and CK reduced in critically } \\
\text { severe patient with a reduction in ground-glass opacity } \\
\text { and pneumonia infiltration }\end{array}$ \\
\hline Liang et al. (161) & Case study & Critical COVID-19 & $\begin{array}{l}\text { Allogenic hUCMSCs at } \\
5 \times 10^{7} \text { cells } 3 \text { times }\end{array}$ & $\begin{array}{l}\text { Admitted } 2 \text { days after } \\
\text { symptoms onset and MSCs } \\
\text { were transplanted on the } 9,12 \text {, } \\
\text { and } 15 \text { th days after admission. } \\
\text { In combination with antibiotics } \\
\text { and thymosin } \alpha 1\end{array}$ & Systemic & $\begin{array}{l}\text { No side effects were observed. After 2nd administration: } \\
-\downarrow \text { Bilirubin, WBC and neutrophil count, CRP and } \\
\text { ALT/AST } \\
-\uparrow \text { lymphocyte count } \\
-\uparrow \mathrm{CD}^{+}, \mathrm{CD} 4^{+} \text {, and } \mathrm{CD} 8^{+} \text {T cells } \\
- \text { Trachea cannula removed } \\
\text { After 3rd administration: } \\
\text { - Pneumonia relieved } \\
\text { - Removed from ICU } 2 \text { days following } \\
\text { - Negative throat swab }\end{array}$ \\
\hline $\begin{array}{l}\text { Zhang et al. } \\
\text { (162) }\end{array}$ & Case study & $\begin{array}{l}\text { COVID-19 pneumonia - } \\
\text { History of diabetes }\end{array}$ & $\begin{array}{l}\text { Wharton's jelly-derived } \\
\text { hUCMSCs at } 1 \times 10^{6} \\
\text { cells/kg }\end{array}$ & $\begin{array}{l}\text { Admitted } 5 \text { days after } \\
\text { symptoms onset and MSCs } \\
\text { were transplanted on the } 17^{\text {th }} \\
\text { day of admission }\end{array}$ & Systemic & $\begin{array}{l}\text { Post-transplant: } \\
\text { - COVID-19 symptoms disappeared } 2 \text { to } 7 \text { days } \\
\text { - } \downarrow \text { Ground glass opacity and pneumonia infiltration day } 6 \\
-\uparrow \mathrm{CD}^{+}, \text {CD } 4^{+} \& \text { CD } 8^{+} \text {T cells } \\
-\downarrow \text { CRP, IL- } 6 \text { \& TNF- } \alpha\end{array}$ \\
\hline Chen et al. (163) & $\begin{array}{l}\text { MSC transplant: } \\
n=17 ; \text { CON: } n=44\end{array}$ & H7N9-induced ARDS & $\begin{array}{l}\text { Allogenic menstrual- } \\
\text { blood-derived MSCs at } \\
1 \times 10^{6} \text { cells } / \mathrm{kg}\end{array}$ & $\begin{array}{l}3 \text { patients treated with } 3 \\
\text { infusion at the early stage of } \\
\text { infection; } 6 \text { patients were } \\
\text { treated with } 3 \text { infusions at the } \\
\text { late stage of infection; } 8 \\
\text { patients accepted } 4 \text { infusions } \\
\text { of at late stage of infection }\end{array}$ & Systemic & $\begin{array}{l}\text { At admission: } \\
\text { - No differences, except } \downarrow \text { PCT vs. CON } \\
\text { At discharge: } \\
\text { - } \uparrow \text { mortality rate of CON } \\
-\downarrow \text { PCT, ALT, sCr, CK, PT, and D-dimer vs. CON } \\
\text { At follow-up (5 year; } n=4) \text { : } \\
-\uparrow \text { Hb } \\
-\downarrow P T\end{array}$ \\
\hline $\begin{array}{l}\text { Sengupta et al. } \\
\text { (164) }\end{array}$ & $N=23$ & $\begin{array}{l}\text { COVID-19: cohort a } \\
\text { (mild COVID-19): } n=1 ; \\
\text { cohort b (hypoxaemia } \\
\text { and COVID-19): } n= \\
\text { 20; cohort c (intubated } \\
\text { COVID-19): } n=3\end{array}$ & $\begin{array}{l}\text { Bone-marrow derived } \\
\text { MSCs exosome } \\
\text { agent-ExoFlow- } \\
-15 \mathrm{~mL}\end{array}$ & Not specified & Systemic & $\begin{array}{l}-71 \% \text { patients recovered and/or were discharged after } \\
5.6 \text { days post-infusion } \\
-13 \% \text { remained critically ill } \\
-16 \% \text { died } \\
-80 \% \text { improved } \mathrm{PaO}_{2} / \mathrm{FiO}_{2} \text { ratio within } 3 \text { days } \\
-\downarrow \mathrm{CRP}, \text { ferritin and } \mathrm{D} \text {-dimer on day } 5 \\
-\uparrow \mathrm{CD} 3^{+}, \mathrm{CD}^{+} \text {, and } \mathrm{CD} 8^{+} T \text { cells on day } 5\end{array}$ \\
\hline
\end{tabular}

CON, control; ACE2, Angiotensin converting enzyme 2; IL-10, Interleukin-10; TNF- $\alpha$, Tumor necrosis factor $\alpha$; IP-10, Interferon gamma-induced protein 10; VEGF, Vascular endothelial growth factor; AST, Aspartate amino transferase; MYO, Myoglobin; CK, Creatine kinase; hUCMSC, human umbilical cord mesenchymal stem cells; WBC, white blood cell; CRP, C-reactive protein; ALT, Alanine aminotransferase; ICU, intensive care unit; ARDS, Acute respiratory distress syndrome; PCT, Procalcitonin; sCr, serum creatinine; PT, Prothrombin time. 
TABLE 2 | List of registered, ongoing, clinical trials using mesenchymal stem/stromal cells (MSCs) as a therapy to treat COVID-19.

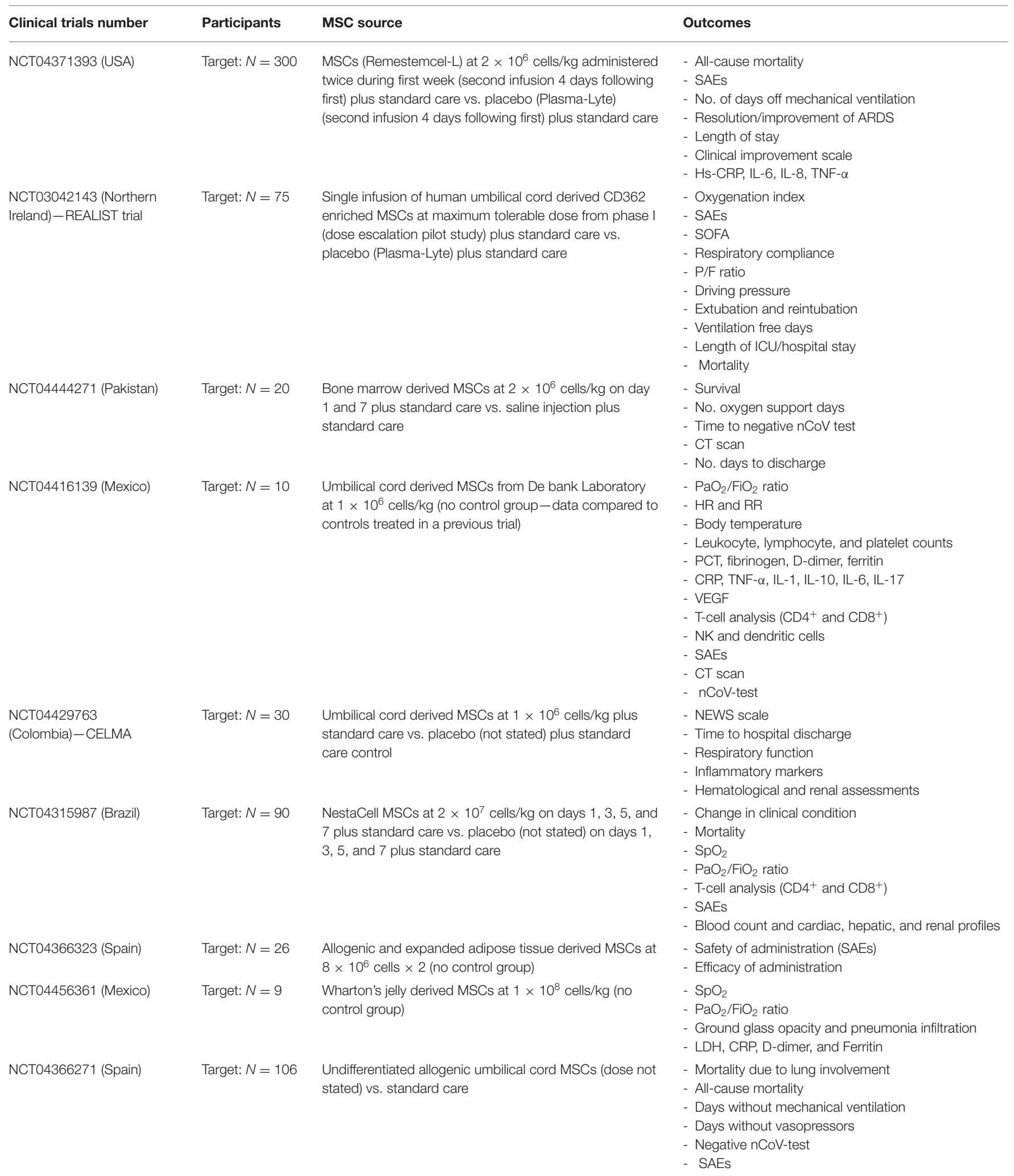


TABLE 2 | Continued

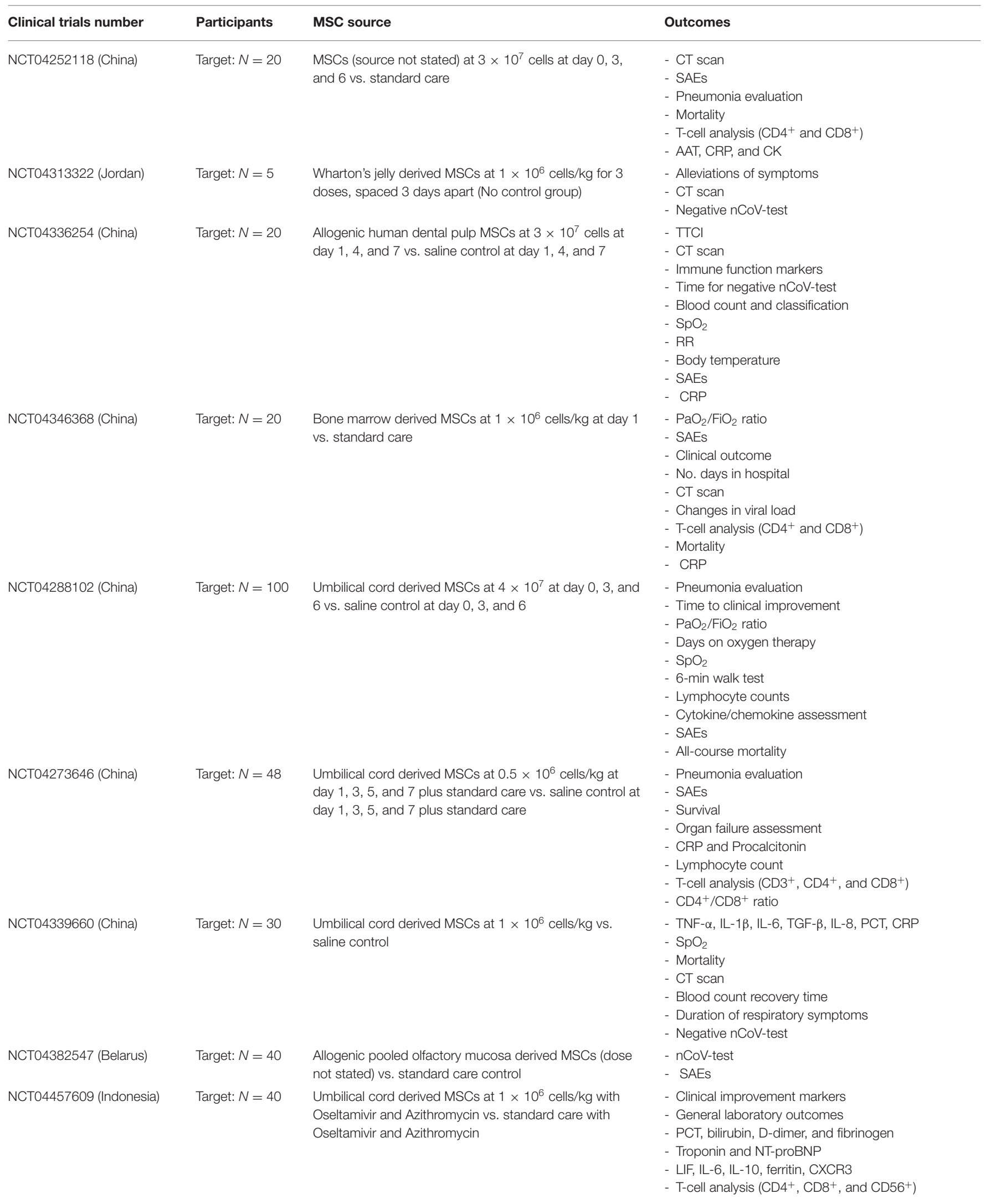


TABLE 2 | Continued

\begin{tabular}{|c|c|c|c|}
\hline Clinical trials number & Participants & MSC source & Outcomes \\
\hline NCT04461925 (Ukraine) & Target: $N=30$ & $\begin{array}{l}\text { Placenta derived MSCs at } 1 \times 10^{6} \text { cells } / \mathrm{kg} \text { once every } 3 \\
\text { days for } 3 \text { infusions vs. standard care control }\end{array}$ & $\begin{array}{l}\text { - } \mathrm{PaO}_{2} / \mathrm{FiO}_{2} \text { ratio } \\
\text { - Length of hospital stay } \\
\text { - Mortality } \\
\text { - CRP } \\
\text { - CT scan } \\
\text { - Duration of respiratory symptoms } \\
\text { - Blood count recovery time }\end{array}$ \\
\hline NCT04362189 (USA) & Target: $N=100$ & $\begin{array}{l}\text { Allogenic adipose tissue derived MSCs (Hope } \\
\text { Biosciences) at } 1 \times 10^{6} \text { cells/dose at day } 0,3,7 \text {, and } 10 \\
\text { vs. saline control at day } 0,3,7 \text {, and } 10\end{array}$ & $\begin{array}{l}\text { - IL-6, CRP, TNF- } \alpha \text {, and IL-10 } \\
\text { - Oxygenation } \\
\text { - RTRA } \\
\text { - ECG assessment } \\
\text { - Routine blood assessments } \\
\text { - Cardiac, hepatic, and renal assessment } \\
\text { - Blood count } \\
\text { - Platelets, Prothrombin time, D-dimer, and INR } \\
\text { - Immune markers } \\
\text { - SAEs } \\
\text { - Chest X-ray } \\
\text { - CT scan } \\
\text { - Negative nCoV-test }\end{array}$ \\
\hline NCT04371601 (China) & Target: $N=60$ & $\begin{array}{l}\text { Umbilical cord derived MSCs at } 1 \times 10^{6} \text { cells } / \mathrm{kg} \text { once } \\
\text { every } 4 \text { days for } 4 \text { infusions vs. standard care control }\end{array}$ & $\begin{array}{l}\text { - } \mathrm{PaO}_{2} / \mathrm{FiO}_{2} \text { ratio } \\
\text { - } \mathrm{TNF}-\alpha \text { and IL-6 } \\
\text { - Immune markers } \\
\text { - } \mathrm{CRP} \text { and calcitonin }\end{array}$ \\
\hline NCT04348461 (Spain) & Target: $N=100$ & $\begin{array}{l}\text { Allogenic expanded adipose tissue derived MSCs at } 1.5 \\
\times 10^{6} \mathrm{cells} / \mathrm{kg} \text { vs. standard care control }\end{array}$ & $\begin{array}{l}\text { - Efficacy of administration of MSCs } \\
\text { - SAEs }\end{array}$ \\
\hline NCT04452097 (USA) & Target: $N=9$ & $\begin{array}{l}\text { Umbilical cord derived MSCs (3 groups): } \\
\text { - Low dose: } 0.5 \times 10^{6} \mathrm{cell} / \mathrm{sg} \\
\text { - Middle dose: } 1 \times 10^{6} \mathrm{cells} / \mathrm{kg} \\
\text { - High dose: } 1.5 \times 10^{6} \mathrm{cells} / \mathrm{kg}\end{array}$ & $\begin{array}{l}\text { - SAEs } \\
\text { - TEAEs } \\
\text { - Selection of appropriate dose for Phase II trial }\end{array}$ \\
\hline NCT04494386 (USA) & Target: $N=60$ & $\begin{array}{l}\text { Umbilical cord lining derived MSCs at } 1 \times 10^{6} \text { cells/dose } \\
\text { vs. saline control-either a single dose or } 2 \text { doses } \\
\text { separated by } 48 \mathrm{~h}\end{array}$ & $\begin{array}{l}\text { - } \mathrm{DLT} \\
\text { - SAEs } \\
\text { - Berlin definition of ARDS } \\
\text { - } \mathrm{SpO}_{2} \text { and } \mathrm{PaO}_{2} / \mathrm{FiO}_{2} \text { ratio } \\
\text { - } \mathrm{No} \text {. of } \mathrm{VFDs} \\
\text { - Blood count } \\
\text { - Routine blood assessments } \\
\text { - BUN and urinalysis } \\
\text { - } \mathrm{AAT}\end{array}$ \\
\hline NCT04345601 (USA) & Target: $N=30$ & $\begin{array}{l}\text { MSCs (source not specified) at } 1 \times 10^{8} \text { cells vs. } \\
\text { standard care control }\end{array}$ & $\begin{array}{l}\text { - SAEs } \\
\text { - Change to clinical status }\end{array}$ \\
\hline
\end{tabular}


TABLE 2 | Continued

\begin{tabular}{|c|c|c|c|}
\hline Clinical trials number & Participants & MSC source & Outcomes \\
\hline NCT04377334 (Germany) & Target: $N=40$ & $\begin{array}{l}\text { Allogenic bone marrow derived MSCs (dose not stated) } \\
\text { vs. standard care control }\end{array}$ & $\begin{array}{l}\text { - Lung injury score } \\
\text { - D-dimer } \\
\text { - Pro-resolving lipid mediators } \\
\text { - Phenotype of immune cells } \\
\text { - Cytokine and chemokine analysis } \\
\text { - Survival } \\
\text { - Extubation } \\
\text { - Lymphocyte subpopulation } \\
\text { - Complement molecules } \\
\text { - SARS-CoV-2 specific antibody }\end{array}$ \\
\hline NCT04390139 (Spain) & Target: $N=30$ & $\begin{array}{l}\text { Wharton's jelly derived MSCs at } 1 \times 10^{6} \text { cells/kg on day } \\
1 \text { and } 3 \text { vs. placebo (not stated) on day } 1 \text { and } 3\end{array}$ & $\begin{array}{l}\text { - All-cause mortality } \\
\text { - SAEs } \\
\text { - Need for mechanical ventilation } \\
\text { - } \mathrm{No} \text {. of } \mathrm{VFDs} \\
\text { - } \mathrm{PaO}_{2} / \mathrm{FiO}_{2} \text { ratio } \\
\text { - SOFA index } \\
\text { - APACHE II score } \\
\text { - Duration of hospitalization } \\
\text { - Immune response } \\
\text { - Feasibility of MSCs } \\
\text { - nCoV-test } \\
\text { - LDH, D-dimer, and ferritin } \\
\text { - Subpopulations of lymphocytes and immunoglobins } \\
\text { - In vitro response of receptor lymphocytes }\end{array}$ \\
\hline NCT04392778 (Turkey) & Target: $N=30$ & $\begin{array}{l}\text { MSCs (source not stated) at } 3 \times 10^{6} \text { cells } / \mathrm{kg} \text { on day } 0 \text {, } \\
3 \text {, and } 6 \text { to COVID- } 19 \text { patients with a ventilator vs. saline } \\
\text { control on day } 0,3 \text {, and } 6 \text { to COVID- } 19 \text { patients with a } \\
\text { ventilator vs. standard care control to COVID- } 19 \text { patients } \\
\text { without a ventilator }\end{array}$ & $\begin{array}{l}\text { - Clinical improvement } \\
\text { - CT scan } \\
\text { - Negative nCoV-test } \\
\text { - Blood tests }\end{array}$ \\
\hline NCT04467047 (Brazil) & Target: $N=10$ & $\begin{array}{l}\text { MSCs (source not stated) at } 1 \times 10^{6} \text { cells } / \mathrm{kg} \text { (safety and } \\
\text { feasibility study) }\end{array}$ & $\begin{array}{l}\text { - Survival } \\
\text { - CRP } \\
\text { - Length of hospital stay } \\
\text { - } \mathrm{PaO}_{2} / \mathrm{FiO}_{2} \text { ratio } \\
\text { - Liao's score (2020) } \\
\text { - CT scan } \\
\text { - Negative nCoV-test }\end{array}$ \\
\hline NCT04437823 (USA) & Target: $N=20$ & $\begin{array}{l}\text { Umbilical cord derived MSCs at } 0.5 \times 10^{6} \mathrm{cell} / \mathrm{sg} \text { on } \\
\text { day } 1,3 \text {, and } 5 \text { vs. standard care control }\end{array}$ & $\begin{array}{l}\text { - SAEs } \\
\text { - CT scan } \\
\text { - Negative nCoV-test } \\
\text { - SOFA score } \\
\text { - Mortality } \\
\text { - Clinical respiratory changes }\end{array}$ \\
\hline NCT04269525 (China) & Target: $N=16$ & $\begin{array}{l}\text { Umbilical cord derived MSCs at } 3.3 \times 10^{7} \text { cells on day } \\
1,3,5 \text {, and } 7\end{array}$ & $\begin{array}{l}\text { - } \mathrm{PaO}_{2} / \mathrm{FiO}_{2} \text { ratio } \\
\text { - Mortality } \\
\text { - Length of hospital stay } \\
\text { - nCoV PCR and antibody-test } \\
\text { - Lung imaging } \\
\text { - WBC and lymphocyte count } \\
\text { - PCT } \\
\text { - IL-2, IL-4, IL-4, IL-6, IL-10, TNF- } \alpha, \gamma-\mathrm{IFN} \text {, and CRP } \\
\text { - NK cells } \\
\text { - T-cell analysis }\left(\mathrm{CD} 4^{+}, \mathrm{CD}^{+}\right)\end{array}$ \\
\hline
\end{tabular}


TABLE 2 | Continued

\begin{tabular}{|c|c|c|c|}
\hline Clinical trials number & Participants & MSC source & Outcomes \\
\hline NCT04333368 (France) & Target: $N=40$ & $\begin{array}{l}\text { Umbilical cord Wharton's jelly derived MSCs at } 1 \times 10^{6} \\
\text { cells/kg at day } 1,3 \text {, and } 5 \text { vs. placebo ( } \mathrm{NaCl} \text { ) control at } \\
\text { day } 1,3 \text {, and } 5\end{array}$ & $\begin{array}{l}\text { - } \mathrm{PaO}_{2} / \mathrm{FiO}_{2} \text { ratio } \\
\text { - Lung injury score } \\
\text { - Mortality } \\
\text { - No. of VFDs } \\
\text { - Use of sedatives } \\
\text { - Use of neuromuscular blocking agent } \\
\text { - ICU-acquired weakness } \\
\text { - SAEs } \\
\text { - Quality of life at } 1 \text { year } \\
\text { - Cytokine analysis } \\
\text { - Anti-HLA antibodies }\end{array}$ \\
\hline NCT04445220 (USA) & Target: $N=22$ & $\begin{array}{l}\text { Allogenic human MSCs at } 2.5 \times 10^{6} \text { cells (low dose) and } \\
7.5 \times 10^{6} \text { cells (high dose) vs. standard care } \\
\text { control-patients with COVID-19 and acute kidney injury }\end{array}$ & $\begin{array}{l}\text { - Safety and tolerability } \\
\text { - SAEs }\end{array}$ \\
\hline NCT04276987 (China) & Target: $N=30$ & $\begin{array}{l}\text { Allogenic adipose tissue derived MSC exosomes inhaled } \\
\text { at } 2 \times 10^{8} \text { nano-vesicles on } 5 \text { consecutive days }\end{array}$ & $\begin{array}{l}\text { - SAEs } \\
\text { - TTCI } \\
\text { - No. of patients weaning from mechanical ventilation } \\
\text { - Vasoactive agent use } \\
\text { - No. of days on mechanical ventilation } \\
\text { - Mortality } \\
\text { - SOFA score } \\
\text { - Lymphocyte count } \\
\text { - CRP, LDH, and D-dimer } \\
\text { - NT-proBNP } \\
\text { - IL-1 } 1 \beta \text {, IL-2R, IL-6, and IL-8 } \\
\text { - Chest imaging } \\
\text { - Negative nCoV-test }\end{array}$ \\
\hline
\end{tabular}


TABLE 2 | Continued

\begin{tabular}{|c|c|c|c|}
\hline Clinical trials number & Participants & MSC source & Outcomes \\
\hline $\begin{array}{l}\text { IRCT20140528017891N8 } \\
\text { (Iran) }\end{array}$ & Target: $N=10$ & $\begin{array}{l}\text { Umbilical cord derived MSCs at } 0.5-1 \text { million cells } / \mathrm{kg} \text { at } \\
1 \mathrm{st} \text {, 3rd, and 6th day vs. saline injection at } 1 \mathrm{st}, 3 \mathrm{rd} \text {, and } \\
\text { 6th day plus standard care }\end{array}$ & $\begin{array}{l}\text { - Mortality } \\
\text { - Pneumonia severity index and CT scan } \\
\text { - } \mathrm{SpO}_{2} \text { supply } \\
\text { - } \mathrm{CRP} \text { and PCT } \\
\text { - Lymphocyte count } \\
\text { - T-cell analysis }\left(\mathrm{CD}^{+}, \mathrm{CD}^{+} \text {, and } \mathrm{CD} 8^{+}\right)\end{array}$ \\
\hline ChiCTR2000030173 (China) & Target: $N=N A$ & Umbilical cord derived vs. standard care control & $\begin{array}{l}\text { - Pulmonary function } \\
\text { - nCoV pneumonic nucleic acid test } \\
\text { - Pulmonary CT and chest radiography }\end{array}$ \\
\hline $\begin{array}{l}\text { CHICTR2000030138 } \\
\text { (China) }\end{array}$ & Target: $N=$ NA & $\begin{array}{l}\text { Umbilical cord derived vs. standard care plus saline } \\
\text { injection control }\end{array}$ & - Clinical index \\
\hline ChiCTR2000030088 (China) & Target: $N=$ NA & $\begin{array}{l}\text { Umbilical cord Wharton's jelly derived MSCs at } 1 \times 10^{6} \\
\text { cells/kg vs. standard care and saline injection control }\end{array}$ & $\begin{array}{l}\text { - nCoV pneumonic nucleic acid test } \\
\text { - CT scan of ground glass shadow }\end{array}$ \\
\hline $\begin{array}{l}\text { CHICTR2000029990; } \\
\text { TARGET N = NA (China) }\end{array}$ & Target: $N=$ NA & $\begin{array}{l}\text { MSCs (source unknown) vs. standard care and saline } \\
\text { injection control }\end{array}$ & $\begin{array}{l}\text { - Respiratory system function }\left(\mathrm{O}_{2} \text { saturation) }\right. \\
\text { recovery time }\end{array}$ \\
\hline CHICTR2000029816 (NA) & Target: $N=N A$ & $\begin{array}{l}\text { Umbilical cord derived MSCs (dose not stated) vs. } \\
\text { standard care control }\end{array}$ & $\begin{array}{l}\text { - Time to disease recovery and time to negative nCoV } \\
\text { test } \\
\text { - Clearance rate and time of main symptoms } \\
\text { - Transfer to ICU time } \\
\text { - Routine blood tests } \\
\text { - Biochemical indicators } \\
\text { - Immune indices }\end{array}$ \\
\hline ChiCTR2000029580 (China) & Target: $N=N A$ & $\begin{array}{l}\text { Ruxolitinib and MSCs (source and dose not stated) vs. } \\
\text { standard care control }\end{array}$ & - Safety \\
\hline $\begin{array}{l}\text { CHICTR2000029569 } \\
\text { (China) }\end{array}$ & Target: $N=N A$ & $\begin{array}{l}\text { Umbilical cord derived blood mononuclear cells } \\
\text { conditioned medium vs. standard care control }\end{array}$ & $\begin{array}{l}\text { - PSI, CT, and X-Ray } \\
\text { - Arterial blood gas } \\
\text { - Assisted breathing time } \\
\text { - Mortality } \\
\text { - Disease evolution } \\
\text { - Hospitalization days } \\
\text { - Safety outcome index }\end{array}$ \\
\hline $\begin{array}{l}\text { EUCTR2020-001450-22- } \\
\text { ES } \\
\text { (Spain) }\end{array}$ & Target: $N=N A$ & Allogenic umbilical cord derived MSCs (dose not stated) & $\begin{array}{l}\text { - Mortality } \\
\text { - Mechanical ventilation incidence } \\
\text { - Need for vasopressors } \\
\text { - Safety profile of MSCs } \\
\text { - Neutrophils, monocytes and NK cells }\end{array}$ \\
\hline
\end{tabular}


TABLE 2 | Continued

\begin{tabular}{|c|c|c|c|}
\hline Clinical trials number & Participants & MSC source & Outcomes \\
\hline & & & $\begin{array}{l}\text { PCT, ferritin, D-dimer and hs-troponin } \\
\text { - PCR test } \\
\text { - B and T lymphocytes } \\
\text { - Interleukins, Th1, 2\&17, NLRP3, and HMGB1 }\end{array}$ \\
\hline $\begin{array}{l}\text { IRCT20200421047150N1 } \\
\text { (Iran) }\end{array}$ & Target: $N=$ NA & $\begin{array}{l}\text { Umbilical card Wharton's jelly derived: three injections at } \\
0.5-1 \text { million cells/kg at } 1 \mathrm{st}, 3 \mathrm{rd} \text {, and 6th day. Control } \\
\text { receiving standard care plus saline injection at } 1 \mathrm{st}, 3 \mathrm{rd} \text {, } \\
\text { and 6th day }\end{array}$ & - Not stated \\
\hline $\begin{array}{l}\text { ACTRN12620000612910 } \\
\text { (Australia) }\end{array}$ & Target: $N=N A$ & $\begin{array}{l}\text { Mesenchymoangioblast derived MSCs (CYP-001) at } 2 \times \\
10^{6} \mathrm{cells} / \mathrm{kg} \text { twice vs. ICU standard care control }\end{array}$ & - Not stated \\
\hline NCT04361942 (Spain) & Target: $N=24$ & $\begin{array}{l}\text { Allogenic MSCs (source unknown) vs. placebo (not } \\
\text { stated) }\end{array}$ & $\begin{array}{l}\text { - Withdrawal of invasive mechanical ventilation } \\
\text { - Mortality } \\
\text { - Patients achieving a clinical response } \\
\text { - Patients achieving a radiological response }\end{array}$ \\
\hline
\end{tabular}

Source: $h$ ttps://clinicaltrials.gov/ct2/home and https://trialstreamer.robotreviewer.net/.

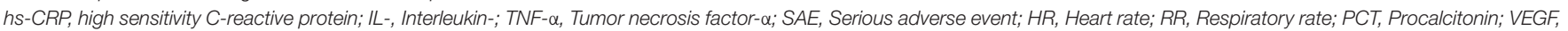

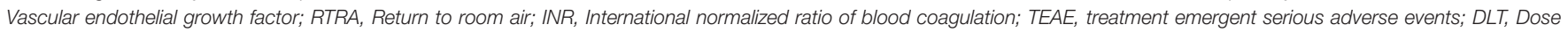

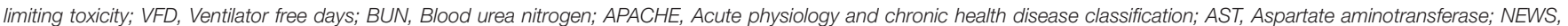

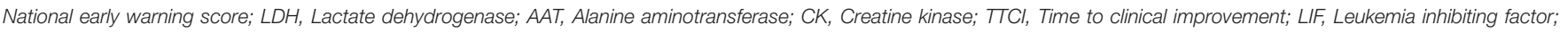

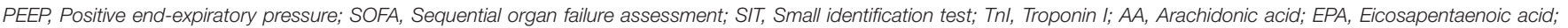
nCoV, novel coronavirus; Polymerase chain reaction; NK, Natural killer; Th, Thelper; NLRP3, NLR Family Pyrin Domain Containing 3; HMGB1, High mobility group box 1.

to myocardial injury, MSC transplantation could offer a cardioprotective role.

\section{MSC TRANSPLANTATION COULD ATTENUATE DAMAGE AND FACILITATE REPAIR OF THE CARDIOVASCULAR SYSTEM SEEN WITH COVID-19}

In addition to the potential for MSCs to modulate the immune response and subsequent tissue damage in COVID-19, there is prospect for MSCs to treat the cardiac and cardiovascular effects of the SARS-CoV-2 virus, which may be long-lasting (Figure 1). As previously discussed, in a large proportion of patients there is evidence of myocardial injury, as suggested by elevated cTnI and cTnT levels $(16,19,168,169)$, and ventricular dysfunction indicated by raised circulating NT-proBNP $(29,31)$. Elevated cardiac biomarkers are associated with more severe prognosis and mortality in COVID-19 patients $(18,26,29,169,170)$, suggesting the cardiac effects of the virus can drive worsening prognosis for the patient. Moreover, there are a number of studies detailing the severe cardiac effects of the virus, such as the development of heart failure (HF) (28), as well as incidences of acute coronary syndromes (ACS) $(171,172)$, ischaemic stroke (173) and myocardial infarction (MI) $(171,172)$. Given the significant deleterious effect of the virus on the myocardium, treatment options to minimize or to alleviate the cardiovascular side effects of the infection and disease are needed.

Treatment with MSCs may offer a clinical benefit to patients due to their regenerative and reparative potential if there is significant myocardial injury and myocardial cell death. There have been a number of studies investigating the use of autologous (174-180) or allogeneic MSCs $(178,181-184)$ for the treatment of cardiomyopathies and post-MI. Although the use of MSCs to treat cardiovascular dysfunction and damage in COVID-19 patients has yet to be fully elucidated, the studies over the past decade provide good preliminary evidence for researchers and clinicians alike to further investigate the use of this cellular therapy in COVID-19 patient cohorts.

Several studies in pig, rat and mouse models of MI showed significant reduction in infarct size or fibrosis (185-194), and improvements in cardiac function $(185-187,189,190,195,196)$. 


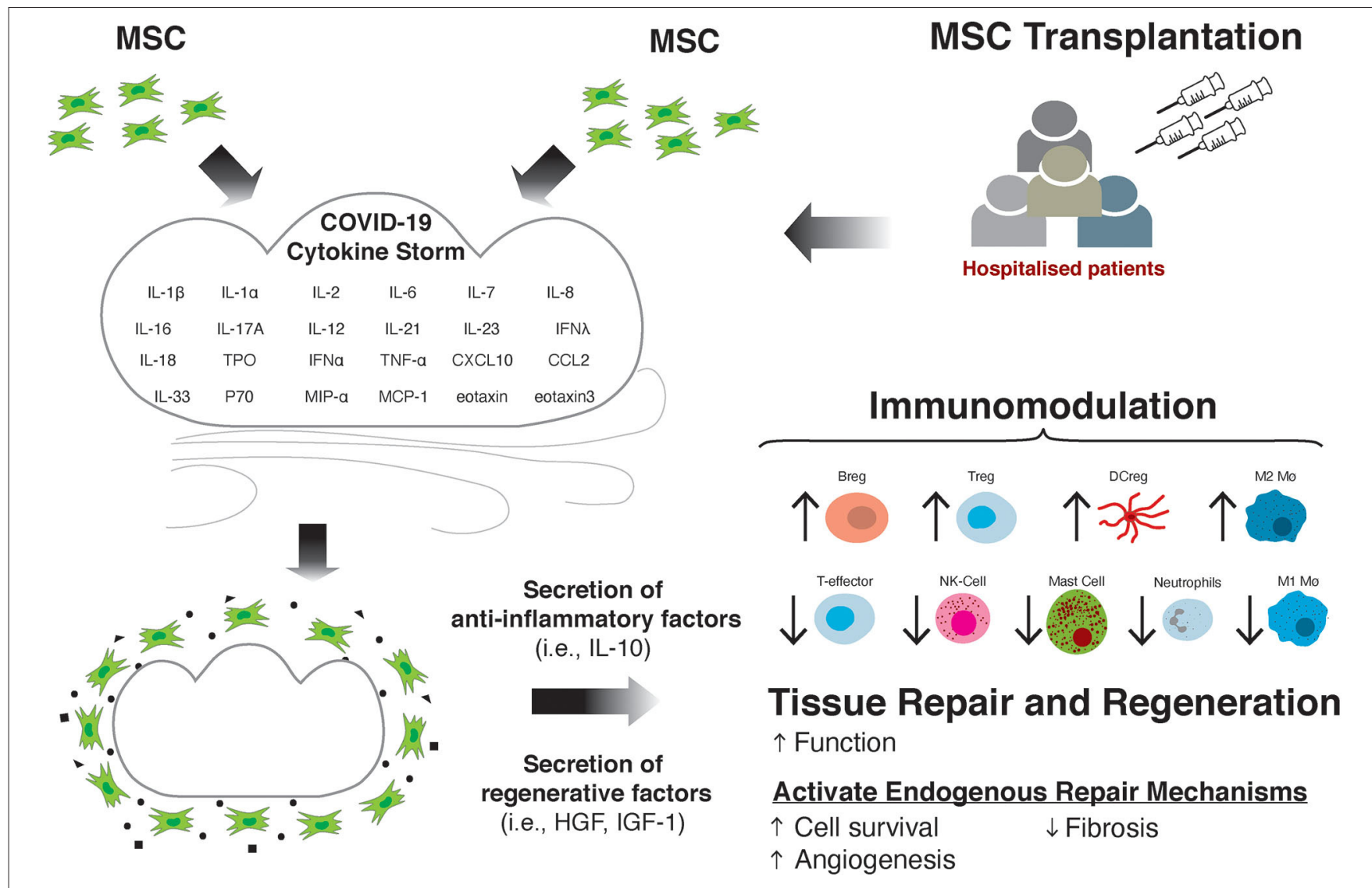

FIGURE 1 | MSC transplantation attenuates the damaging effects of the cytokine storm through immunomodulation and improving tissue repair and regeneration.

A meta-analysis of 52 pre-clinical animal studies of cell therapy for ischaemic heart disease reported that MSC therapy is safe and associated with significant $\sim 7.5 \%$ improvements in LVEF (197). In order to elicit increased efficacy, cell combination therapy has been investigated. In swine models of MI, human bone marrowderived MSCs and cardiac-derived stromal MSC stem/progenitor cells from autologous or allogeneic sources were co-injected into the border zone of the infarct. Results showed that by combining the cell types there was greater therapeutic efficacy, improving cardiac repair/regeneration and LV functional recovery without adverse immunologic reaction $(198,199)$.

These promising findings have been followed by a number of human clinical trials. In a number of these human studies, the infusion and transplantation of MSCs have been deemed safe for treating MI patients $(179,200)$ as well as having been successful in improving some cardiac functional measures post-MI, such as $\operatorname{LVEF}(175,177,200-204)$, and improving global longitudinal strain measures (201). Penn et al. (204) showed in a phase I clinical trial in patients with first ST-elevation-myocardial infarction (STEMI), delivery of MSCs (MultiStem) using a coronary adventitial delivery system was well-tolerated and safe. In patients who exhibited significant myocardial damage, the delivery of $\geq 50$ million MultiStem resulted in improved EF and stroke volume 4 months later (204). However, some of these studies, and others, found no difference between MSC treatment and no treatment/placebo on infarct size or perfusion changes in the months following the enrolment to the study $(177,205$, 206). Additionally, several human studies fail to observe any clinical benefit for patients $(179,184,205,207)$. Inconsistent findings are likely due to the number and phenotype of MSCs being transplanted, their source, as well as mode and location of administration (myocardial, epicardial, or endocardial injection; systemic transplantation).

Despite mixed findings on the efficacy for improving cardiac function, MSCs can offer potential as regenerative cells for the $\mathrm{CV}$ system, where through a paracrine mechanism they activate endogenous repair mechanisms leading to blood vessel growth via angiogenesis, improved cardiomyocyte survival, reduced cardiomyocyte reactive hypertrophy, and fibrosis (Figure 1). We have clonally derived (from a single cell) a population of stromal cells with multipotent stem/progenitor cell properties from the adult mammalian heart, including human (208210). These cells produce a repertoire of pro-survival and cardiovascular regenerative growth factors. We administered these cells intracoronary at differential doses $\left(5 \times 10^{6}, 5 \times\right.$ $10^{7}$, and $1 \times 10^{8}$ ) in three groups of white Yorkshire female 
pigs with MI, $30 \mathrm{~min}$ after coronary reperfusion. Pig serum was injected to six control pigs after MI. We found a high degree of cell engraftment in the damaged pig myocardium. By 3 weeks after MI and cell transplantation, there was increased new cardiomyocyte and capillary formation, which was not evident in the control hearts (194). Moreover, cell treatment preserved myocardial wall structure and attenuated remodeling by reducing cardiomyocyte hypertrophy, apoptosis, and scar formation (fibrosis) (211).

In mouse, rat and in vitro cell model studies, MSCs have been found to be potently angiogenic (192, 212-221). As outlined previously, MSCs most likely promote angiogenesis via paracrine means, such as secretion of angiogenic factors; vascular endothelial growth factor (VEGF), basic fibroblast growth factor (bFGF), transforming growth factor beta (TGF- $\beta$ ), and plateletderived growth factor (PDGF) $(222,223)$, which are promoted under hypoxic conditions (224). Proteomic analysis of secreted exosomes, which carry lipids, proteins and genetic material to target tissues, from MSCs reveal several target pathways (225). These include inflammation and angiogenesis, of which, the angiogenesis pathway revealed specific interaction with NF-K-B signaling. When these exosomes were cultured with HUVECs, a significant increase in endothelial tube formation was detected in a dose-dependent fashion (225). Zhang et al. (226) investigated the potential for MSC-derived exosomes to promote angiogenesis and cardiac repair post-MI in rats. Firstly, they observed that exosomes isolated from MSCs promoted tube formation of cardiac stem/progenitor cells in vitro. They subsequently transplanted cardiac stem/progenitor cells internalized with these exosomes into a rat model of MI, and observed an increased capillary density, which was followed by an improvement in LVEF, and reduction in fibrosis after 28 days post-implantation. Interestingly, the source of MSCs can significantly alter their proangiogenic potential. Du et al. (219) isolated MSCs from bone marrow, adipose tissue, umbilical cord and placenta and assessed their pro-angiogenic capacity using in vitro tube formation assays, as well as endothelial cell proliferation and assessment of angiogenic gene expression by RT-PCR. They found that MSCs isolated from the bone marrow and the placenta promoted angiogenesis in vitro to a greater extent than MSCs from adipose tissue and umbilical cord. In addition, they found that MSCs from these sources had a greater expression of VEGF mRNA and protein (219).

As well as promoting angiogenesis, MSCs may promote recovery from cardiac injury/insult by differentiating into mature cardiomyocytes, or by promoting resident cardiomyocyte proliferation. Mesenchymal stromal cells have a broad differentiation capacity, and have been shown to be able to differentiate into osteoblasts (227), neuronal cells (228) as well as upregulate cardiomyocyte markers, such as cardiac myosin heavy chain (229) and troponin T $(229,230)$. However, several studies have failed to observe significant trans-differentiation of MSCs into either endothelial cells or functional cardiomyocytes $(189,231,232)$. Otherwise, MSCs have been found to promote cardiomyocyte DNA synthesis and proliferation, and signal cardiomyocyte gene upregulation (including VEGF, cyclin A2, and TGF- $\beta 2)(194,233)$. Through their paracrine activity, they also prevent cardiomyocyte cell apoptosis $(188,221,234-$ 236) with several studies observing a reduced activation of the caspase-3 pathway in cardiomyocytes exposed to either MSC-derived exosomes (236) or conditioned media (237).

Other methods to maximize cellular function of cell therapies include "priming" which involves promoting expression of certain receptors, proteins and cytokines in the cells prior to transplantation or infusion. Mesenchymal stromal cells primed in vitro, prior to in vivo administration may offer opportunity to improve the efficacy of MSC treatment. Several studies have shown that by priming these cells in vitro, for example to highly express GATA-4 (MSC ${ }^{\mathrm{GATA}-4}$ ) (238), or CXCR4 (MSC ${ }^{\text {CXCR4}}$ ) $(233,239)$ may improve the angiogenic paracrine activity of these cells. Mesenchymal stromal cells which were overexpressing GATA-4 contained more VEGF and IGF-1 protein, which, when blocked with neutralizing antibodies, attenuated the proangiogenic activity of $\mathrm{MSC}^{\mathrm{GATA}-4}$ (238). Moreover, cardiacderived stem/progenitor cells that express high levels of GATA4 have shown to foster cardiomyocyte survival through IGF1 paracrine signaling (240). MSC ${ }^{\text {CXCR4 }}$ cells themselves were found to be highly angiogenic compared to un-primed MSCs, with greater expression of VEGF, which may partly explain the greater in vitro tube formation observed in a study by Zhang et al. (239). CXCR4 over-expression may be beneficial in promoting cell migration to ischaemic tissue due to the ligand stromal-derived factor-1 (SDF-1) (241), which is released in ischaemic tissue $(242,243)$. Thus, by selecting CXCR4 ${ }^{+}$MSCs, or promoting CXCR4 expression in vitro, MSC migration to target infarct or damaged areas may be improved, subsequently allowing the cells to stimulate repair in the area required more efficiently.

Heart tissue damage post-MI, although largely due to ischaemic tissue injury and insult and associated cardiomyocyte loss, is also due to inflammation associated in the hours and days post-MI $(244,245)$. This inflammatory response is associated with further cardiac tissue damage and injury, as indicated by sustained and continual increases in cTnI and cTnT (246). Indeed MSC exosomes can regulate T-cell proliferation (215) as well as alter the balance between M1 and M2 macrophages in the infarcted heart (191), and the number of neutrophils and NK cells post-MI in the cardiac tissue (244) suggesting strong anti-inflammatory properties of the MSCs. In fact, a study by Luger et al. (244) found that MSC exosomes were able to reduce the number of NK cells in cardiac tissue postMI, followed by a separate experiment whereby depleting NK cells $24 \mathrm{~h}$ prior to $\mathrm{MI}$ in mice, reduced the resulting infarct size. These findings infer that NK cells are involved in causing, or significantly contributing to, the cardiac damage resulting from an ischaemic challenge, and that MSCs could attenuate this inflammation. Taken together, it appears that MSCs also promote cardiac recovery via attenuating the ongoing inflammatory response, which is also a likely pathway for COVID-19-associated myocardial injury.

Although there is significant promise in the use of MSCs for cellular therapy to treat cardiovascular conditions, their efficacy for use in treating COVID-19-related cardiac dysfunction and injury is yet to be determined. 


\section{MSC TRANSPLANTATION IN COVID-19 PATIENTS COULD ALLEVIATE PULMONARY FIBROSIS}

Fibrotic disorders in the lung, such as idiopathic pulmonary fibrosis (IPF), share similar comorbidities with COVID-19. Both conditions are progressive in nature, often because of worsening lung injury and fibrosis of alveolar walls. This underscores a common anti-fibrotic strategy.

Clinical trials with anti-fibrotic agents have shown promise in reversing progression of pulmonary fibrosis, as evidenced with nintedanib (247) and pirfenidone (248), which were approved by the FDA more than 6 years ago (249). This is supported by findings from pre-clinical animal models. An animal model of IPF with increased fibrosis and defective clearance of fibrocytes and myofibroblasts, was improved upon treatment with nintedanib (250). However, whether these agents will have clinical efficacy in COVID-19 remains unknown. Notably, commercial anti-fibrotic drugs, such as nintedanib and pirfenidone, are only available for oral delivery. This limits their use in COVID-19 patients, given that the population with fibrotic lung damage are usually hospitalized and intubated. Moreover, the hepatoxic side effects of both drugs and the contraindication of pirfenidone in renal dysfunction further limit their use, especially noting that SARS-CoV-2 is associated with development of both liver and kidney dysfunctions $(58,251)$. This highlights the need for better therapeutic strategies for lung fibrosis. Novel treatment options, such as cell-based therapy for replenishing lost functional capacity of resident stromal cells, have great potential for patients with COVID-19.

Cell-based therapy has been keenly investigated in the preclinical models using bleomycin-induced pulmonary fibrosis. Bleomycin-induced lung injury is a well-characterized model of human pulmonary fibrosis, with an initial phase of inflammatory activation and consequent fibrosis. In mice, intravenous injection of the primary human amniotic epithelial cells (hAECs) reduced lung inflammation and expression of the pro-fibrotic ligand TGF$\beta 1$ (252). Human amniotic epithelial cells transplantation also reduced the Ashcroft score, a validated marker of severity of lung fibrosis (253), likely due to increased degradation by matrix metalloproteinase (MMP)-2 and reduced expressions of tissue inhibitors of MMPs (TIMP)-1 and 2 (252). A pooled analysis of pre-clinical evidence demonstrated significantly better results on Ashcroft score and collagen contents for hAECs compared to placebo (254). Much akin to hAECs, MSCs have been shown to ameliorate pulmonary injury induced by bleomycin in experimental models (255). This has been demonstrated for bone marrow, umbilical cord, and amniotic fluid derived MSCs, respectively. The therapeutic efficacy of MSCs is also reported in other models of lung fibrosis. For example, adipose tissue-derived MSCs significantly attenuated lung function and fibrosis in a rodent model of silica-induced lung fibrosis (256). In summary, these data show that MSC-based therapy is a promising tool to address the pathophysiological consequences of COVID19 in the lung. However, clinical translation would require more refined understanding of the anti-fibrotic mechanisms of MSCs.
Cumulative data show that MSCs protect against fibrosis via hepatocyte growth factor (HGF)-mediated mechanisms. Hepatocyte growth factor was originally identified as a mitogen for hepatocytes. It has now been shown to mediate mitogenic, anti-inflammatory, anti-apoptotic, and regenerative effects during tissue repair. In models of I/R lung injury, transplanted HGF-overexpressed MSCs resulted in lessened oxidative stress, inflammation, and attenuated lung injury (257). Hepatocyte growth factor also prolonged the survival of engrafted MSCs via increased expression of the anti-apoptotic protein Bcl-2 and repression of caspase- 3 activation. In the context of fibrosis, there is evidence to suggest that HGF modulates pro-fibrotic pathways. For instance, microvesicles from human Wharton's Jelly MSCs inhibited apoptosis, fibrosis in pulmonary tissues, and activation of $\mathrm{PI} 3 \mathrm{~K} / \mathrm{AKT} / \mathrm{mTOR}$ pathway (258). These effects were blocked by using HGF-mRNAdeficient microvesicles or PI3K inhibitor. Hepatocyte growth factor also inhibits alveolar epithelial-to-mesenchymal transition and production of TGF- $\beta 1$ independent of MSCs (259).

Other pathways have also been implicated in mediating the anti-fibrotic role of MSCs, including the activation of MMP-9 (260), programmed death (PD)-1/PD-L1 (261), and anti-apoptotic Bcl-2 $(256,257)$. MMP-9 is said to promote the degradation of collagen deposits, thereby facilitating the repair process following lung injury. On the other hand, MSC transplantation has been associated with repressed TGF- $\beta 1 /$ SMAD3 (255), Wnt/ $\beta$-catenin signaling (262), MyD88/TGF- $\beta 1$ signaling (263), and $\mathrm{N}$-methyl-d-aspartate receptor activity (264). Inhibition of $\mathrm{Wnt} / \beta$-catenin signaling has a two-fold function. Firstly, it prevents downstream activation of pro-fibrotic genes and development of fibrosis; and, secondly, it rescues lung resident MSCs from differentiating to myofibroblasts (265).

Whether similar benefits will be seen in COVID-19 patients remains to be established. A single center, non-randomized, doseescalation phase $1 \mathrm{~b}$ trial of eight patients with moderate-to-severe IPF treated with intravenous bone marrow-derived MSC showed a good short-term safety profile (266). CT fibrosis score did not change 6 months after administration compared to baseline; however, there was no further worsening of fibrosis during follow-up. Similar findings were noted in a larger (randomized) trial of 20 IPF patients treated with high-dose bone marrowderived MSCs (267). Subsequently, a trial of 61 patients with influenza A (H7N9)-induced ARDS showed significant reduction in the inflammatory marker CRP following menstrual-bloodderived MSC treatment, compared to placebo (163). While treated patients showed linear fibrosis, ground-glass opacity, and pleural thickening on chest $\mathrm{CT}$ at baseline, there was improvement in all patients after 24 weeks and up to 1 year after MSC treatment.

Our current understanding of the mechanisms of MSCmediated improvement in lung (fibrotic) injury is incomplete, especially in the context of COVID-19. There are other important questions that will need to be addressed, too. For instance, would the MSCs need to be primed for improved efficacy? Previous studies have shown that pre-conditioning of MSCs with oncostatin M $(268,269)$, low-dose TGF- $\beta 1$ (270), IL-6 
(269), or ischaemia (271) improves the survival and therapeutic benefits. Obtaining the best MSCs for transplantation in terms of optimum immunomodulatory capacity and availability should be considered in COVID-19 studies. Primary MSCs, such as those obtained from bone marrow, umbilical cord, or adipose tissue, are limited by lack of available donors, many lack standardized preparations, with variations in quality, limited regenerative capacity, and finite lifespans. To overcome these limitations, a recent study investigated a novel hESC-derived MSC-like cell population, termed Immunity-and Matrix-Regulatory Cells (IMRCs) (272). Produced to good manufacturing standards, IMRCs demonstrated excellent safety and efficacy profiles in in vivo models of mice and monkeys. Additionally, IMRCs demonstrated superior immunomodulatory effects compared to umbilical cord-derived MSCs and the anti-fibrotic agent, pirfenidone (272).

\section{CONCLUSION}

Evidence now supports severe COVID-19 being associated with a dysregulated and hyperactive inflammatory systemic response; a cytokine storm. Older people ( $>60$ years) and people with comorbidities are more likely to develop a dysfunctional immune response, and resultant cytokine storm, that causes pathology and fails to successfully eradicate the pathogen. The exact reasons for this are unclear, although one reason may be a decline in immune function with age and chronic sterile inflammation due

\section{REFERENCES}

1. Rosenwald SM. History's deadliest pandemics, from ancient Rome to modern America | The Spokesman-Review. The Spokesman-Review. (2020) Available online at: https:/www.spokesman.com/stories/2020/apr/15/ historys-deadliest-pandemics-from-ancient-rome-to-/ (accessed August $23,2020)$.

2. Gagnon A, Miller MS, Hallman SA, Bourbeau R, Herring DA, Earn DJD, et al. Age-specific mortality during the 1918 influenza pandemic: unravelling the mystery of high young adult mortality. PLoS ONE. (2013) 8:e69586. doi: 10.1371/journal.pone.0069586

3. Morens DM, Fauci AS. The 1918 influenza pandemic: insights for the 21 st century. J Infect Dis. (2007) 195:1018-28. doi: 10.1086/511989

4. Yan R, Zhang Y, Li Y, Xia L, Guo Y, Zhou Q. Structural basis for the recognition of SARS-CoV-2 by full-length human ACE2. Science. (2020) 367:1444-8. doi: 10.1126/science.abb2762

5. Hoffmann M, Kleine-Weber H, Schroeder S, Mü MA, Drosten C, Pö S. SARS-CoV-2 cell entry depends on ACE2 and TMPRSS2 and is blocked by a clinically proven protease inhibitor. Cell. (2020) 181:271-80.e8. doi: 10.1016/j.cell.2020.02.052

6. Aimes TR, Zijlstra A, Hooper DJ, Ogbourne MS, Sit M-L, Fuchs $\mathrm{S}$, et al. Endothelial cell serine proteases expressed during vascular morphogenesis and angiogenesis. Thombosis Haemost. (2003) 89:561-72. doi: $10.1055 /$ s-0037-1613388

7. Pan X-W, Xu D, Zhang H, Zhou W, Wang L-H, Cui X-G. Identification of a potential mechanism of acute kidney injury during the COVID-19 outbreak: a study based on single-cell transcriptome analysis. Intensive Care Med. (2020) 46:1114-6. doi: 10.1007/s00134-020-06026-1

8. Sungnak W, Huang N, Bécavin C, Berg M, Queen R, Litvinukova M, et al. SARS-CoV-2 entry factors are highly expressed in nasal epithelial cells together with innate immune genes. Nat Med. (2020) 26:681-7. doi: 10.1038/s41591-020-0868-6 to the build-up of senescent cells and immunosenescence in aging humans (273).

The manifestations of elevated pro-inflammatory, sustained circulating factors due to the cytokine storm are not just confined to the lungs, with significant damage to the CV system and multi-organ damage and dysfunction. Interventions that target single cytokines (i.e., Tocilizumab targeting IL-6) do not seem efficacious in reducing mortality. Mesenchymal stromal cells owing to their powerful immunomodulatory function can holistically target and suppress the cytokine storm. At the same time, MSC transplantation is safe and has proven effective at activating endogenous repair mechanisms, leading to improved cardiac function, tissue regeneration and decreased fibrosis. Therefore, attenuating persistent organ dysfunction. Further mechanistic studies are required to investigate if MSC therapy can alleviate the cardiovascular consequences of COVID-19, and thus reduce cardiovascular risk in these patients. Work should also focus on determining the optimal dose, timing of injections (multiple dosing at different stages of the disease), systemic distribution of transplanted cells, type of MSCs used or use of exosomes, and the anti-viral effects of MSC transplantation.

\section{AUTHOR CONTRIBUTIONS}

LC put together the tables. TA put together the figure. GE-H oversaw the completion of the article. All authors contributed to writing the article.
9. Chen L, Li X, Chen M, Feng Y, Xiong C. The ACE2 expression in human heart indicates new potential mechanism of heart injury among patients infected with SARS-CoV-2. Eur Soc Cardiol. (2020) 116:1097-100. doi: $10.1093 / \mathrm{cvr} / \mathrm{cvaa} 078$

10. Meselson M. Droplets and aerosols in the transmission of SARS-CoV-2. N Engl J Med. (2020) 382:2063. doi: 10.1056/NEJMc2009324

11. Huang C, Wang Y, Li X, Ren L, Zhao J, Hu Y, et al. Clinical features of patients infected with 2019 novel coronavirus in Wuhan, China. Lancet. (2020) 395:497-506. doi: 10.1016/S0140-6736(20)30183-5

12. Kaye R, Chang CWD, Kazahaya K, Brereton J, Denneny JC. COVID19 anosmia reporting tool: initial findings. Otolaryngol Head Neck Surg (United States). (2020) 163:132-4. doi: 10.1177/0194599820922992

13. Weiss ARR, Dahlke MH. Immunomodulation by mesenchymal stem cells (MSCs): mechanisms of action of living, apoptotic, and dead MSCs. Front Immunol. (2019) 10:1191. doi: 10.3389/fimmu.2019.01191

14. Golchin A, Seyedjafari E, Ardeshirylajimi A. Mesenchymal stem cell therapy for COVID-19: present or future. Stem Cell Rev Rep. (2020) 16:427-33. doi: 10.1007/s12015-020-09973-w

15. Golchin A, Farahany TZ, Khojasteh A, Soleimanifar F, Ardeshirylajimi A. The clinical trials of mesenchymal stem cell therapy in skin diseases: an update and concise review. Curr Stem Cell Res Ther. (2018) 14:22-33. doi: 10.2174/1574888x13666180913123424

16. Zhou F, Yu T, Du R, Fan G, Liu Y, Liu Z, et al. Clinical course and risk factors for mortality of adult inpatients with COVID-19 in Wuhan, China: a retrospective cohort study. Lancet. (2020) 395:1054-62. doi: 10.1016/S0140-6736(20)30566-3

17. Grasselli G, Zangrillo A, Zanella A, Antonelli M, Cabrini L, Castelli A, et al. Baseline characteristics and outcomes of 1591 patients infected with SARS-CoV-2 admitted to ICUs of the Lombardy Region, Italy. JAMA. (2020) 323:1574-81. doi: 10.1001/jama.2020.5394

18. Shi S, Qin M, Shen B, Cai Y, Liu T, Yang F, et al. Association of cardiac injury with mortality in hospitalized patients with COVID-19 in 
Wuhan, China. JAMA Cardiol. (2020) 5:802-10. doi: 10.1001/jamacardio. 2020.0950

19. Wang D, Hu B, Hu C, Zhu F, Liu X, Zhang J, et al. Clinical characteristics of 138 hospitalized patients with 2019 novel coronavirus-infected pneumonia in Wuhan, China. JAMA. (2020) 323:1061-9. doi: 10.1001/jama. 2020.1585

20. Léonard-Lorant I, Delabranche X, Séverac F, Helms J, Pauzet C, Collange O, et al. Acute pulmonary embolism in patients with COVID-19 at CT angiography and relationship to d-Dimer levels. Radiology. (2020) 296:E18991. doi: 10.1148/radiol.2020201561

21. Poissy J, Goutay J, Caplan M, Parmentier E, Duburcq T, Lassalle F, et al. Pulmonary embolism in patients with COVID-19: awareness of an increased prevalence. Circulation. (2020) 142:184-6. doi: 10.1161/CIRCULATIONAHA.120.047430

22. Sala S, Peretto G, Gramegna M, Palmisano A, Villatore A, Vignale D, et al. Acute myocarditis presenting as a reverse Tako-Tsubo syndrome in a patient with SARS-CoV-2 respiratory infection. Eur Heart J. (2020) 41:1861-2. doi: 10.1093/eurheartj/ehaa286

23. Kim IC, Kim JY, Kim HA, Han S. COVID-19-related myocarditis in a 21-year-old female patient. Eur Heart J. (2020) 41:1859. doi: 10.1093/eurheartj/ehaa288

24. Clerkin KJ, Fried JA, Raikhelkar J, Sayer G, Griffin JM, Masoumi A, et al. COVID-19 and cardiovascular disease. Circulation. (2020) 141:1648-55. doi: 10.1161/CIRCULATIONAHA.120.046941

25. Roberts KA, Colley L, Agbaedeng TA, Ellison-Hughes GM, Ross MD. Vascular manifestations of COVID-19-thromboembolism and microvascular dysfunction. Front Cardiovasc Med. (2020) 7:598400. doi: $10.3389 /$ fcvm. 2020.598400

26. Deng Q, Hu B, Zhang Y, Wang H, Zhou X, Hu W, et al. Suspected myocardial injury in patients with COVID-19: evidence from front-line clinical observation in Wuhan, China. Int J Cardiol. (2020) 311:116-21. doi: 10.1016/j.ijcard.2020.03.087

27. Santoso A, Pranata R, Wibowo A, Al-Farabi MJ, Huang I, Antariksa B. Cardiac injury is associated with mortality and critically ill pneumonia in COVID-19: a meta-analysis. Am J Emerg Med. (in press). doi: 10.1016/j.ajem.2020.04.052

28. Chen T, Wu D, Chen H, Yan W, Yang D, Chen G, et al. Clinical characteristics of 113 deceased patients with coronavirus disease 2019: retrospective study. BMJ. (2020) 368:m1091. doi: 10.1136/bmj.m1091

29. Guo T, Fan Y, Chen M, Wu X, Zhang L, He T, et al. Cardiovascular implications of fatal outcomes of patients with coronavirus disease 2019 (COVID-19). JAMA Cardiol. (2020) 5:811-8. doi: 10.1001/jamacardio.2020.1017

30. Guan W, Ni Z, Hu Y, Liang W, Ou C, He J, et al. Clinical characteristics of coronavirus disease 2019 in China. N Engl J Med. (2020) 382:1708-20. doi: 10.1056/NEJMoa2002032

31. Han H, Xie L, Liu R, Yang J, Liu F, Wu K, et al. Analysis of heart injury laboratory parameters in 273 COVID-19 patients in one hospital in Wuhan, China. J Med Virol. (2020) 92:819-23. doi: 10.1002/jmv.25809

32. Danzi GB, Loffi M, Galeazzi G, Gherbesi E. Acute pulmonary embolism and COVID-19 pneumonia: a random association? Eur Heart J. (2020) 41:1858. doi: 10.1093/eurheartj/ehaa254

33. Tay MZ, Poh CM, Rénia L, MacAry PA, Ng LFP. The trinity of COVID19: immunity, inflammation and intervention. Nat Rev Immunol. (2020) 20:363-74. doi: 10.1038/s41577-020-0311-8

34. Merad M, Martin JC. Pathological inflammation in patients with COVID19: a key role for monocytes and macrophages. Nat Rev Immunol. (2020) 20:355-62. doi: 10.1038/s41577-020-0331-4

35. Ferrara JLM, Abhyankar S, Gilliland DG. Cytokine storm of graft-versushost disease: a critical effector role for interleukin-1. Transpl Proc. (1993) 56:1518-23. doi: 10.1097/00007890-199312000-00045

36. Yuen K, Wong S. Human infection by avian influenza A H5N1. Hong Kong Med. (2005) 11:189-199.

37. Noroozi R, Branicki W, Pyrc K, Łabaj PP, Pospiech E, Taheri M, et al. Altered cytokine levels and immune responses in patients with SARSCoV-2 infection and related conditions. Cytokine. (2020) 133:155143. doi: $10.1016 /$ j.cyto.2020.155143
38. Blanco-Melo D, Nilsson-Payant BE, Liu W-C, Lim JK, Albrecht RA, Tenoever BR. Imbalanced host response to SARS-CoV-2 drives development of COVID-19. Cell. (2020) 181:1036-45. doi: 10.1016/j.cell.2020.04.026

39. Chen G, Wu D, Guo W, Cao Y, Huang D, Wang H, et al. Clinical and immunological features of severe and moderate coronavirus disease 2019. J Clin Invest. (2020) 130:2620-9. doi: 10.1172/JCI137244

40. Liu J, Li S, Liu J, Liang B, Wang X, Wang H, et al. Longitudinal characteristics of lymphocyte responses and cytokine profiles in the peripheral blood of SARS-CoV-2 infected patients. EBioMedicine. (2020) 55:102763. doi: 10.1016/j.ebiom.2020.102763

41. Del Valle DM, Kim-Schulze S, Hsin-Hui H, Beckmann ND, Nirenberg S, Wang B, et al. An inflammatory cytokine signature helps predict COVID19 severity and death. medRxiv Prepr Serv Heal Sci. [Preprint] (2020). doi: 10.1101/2020.05.28.20115758

42. Lucas C, Wong P, Klein J, Castro TBR, Silva J, Sundaram M, et al. Longitudinal analyses reveal immunological misfiring in severe COVID-19. Nature. (2020) 584:463. doi: 10.1038/s41586-020-2588-y

43. Laing AG, Lorenc A, Del Molino Del Barrio I, Das A, Fish M, Monin L, et al. A dynamic COVID-19 immune signature includes associations with poor prognosis. Nat Med. (2020) 26:1-13. doi: 10.1038/s41591-020-1038-6

44. Guo C, Li B, Ma H, Wang X, Cai P, Yu Q, et al. Single-cell analysis of two severe COVID-19 patients reveals a monocyte-associated and tocilizumab-responding cytokine storm. Nat Commun. (2020) 11:1-11. doi: 10.1038/s41467-020-17834-w

45. Mehta P, McAuley DF, Brown M, Sanchez E, Tattersall RS, Manson JJ. COVID-19: consider cytokine storm syndromes and immunosuppression. Lancet. (2020) 395:1033-4. doi: 10.1016/S0140-6736(20)30628-0

46. Pedersen SF, Ho YC. SARS-CoV-2: a storm is raging. J Clin Invest. (2020) 130:2202-5. doi: 10.1172/JCI137647

47. Ruan Q, Yang K, Wang W, Jiang L, Song J. Clinical predictors of mortality due to COVID-19 based on an analysis of data of 150 patients from Wuhan, China. Intensive Care Med. (2020) 46:846-8. doi: 10.1007/s00134-020-05991-x

48. Aggarwal NR, King LS, D’Alessio FR. Diverse macrophage populations mediate acute lung inflammation and resolution. Am J Physiol Lung Cell Mol Physiol. (2014) 306:709-25. doi: 10.1152/ajplung.00341.2013

49. D’Alessio FR, Tsushima K, Aggarwal NR, West EE, Willett MH, Britos MF, et al. $\mathrm{CD} 4^{+} \mathrm{CD} 25^{+} \mathrm{Foxp}^{+}$tregs resolve experimental lung injury in mice and are present in humans with acute lung injury. J Clin Invest. (2009) 119:2898-913. doi: $10.1172 / \mathrm{JCI} 36498$

50. Geiser T, Atabai K, Jarreau P-H, Ware BL, Pugin JR, Matthay AM. Pulmonary edema fluid from patients with acute lung injury augments in vitro alveolar epithelial repair by an IL-1b-dependent mechanism. Am J Respir Crit Care Med. (2001) 163:1384-8. doi: 10.1164/ajrccm.163.6.2006131

51. Han S, Mallampalli RK. The acute respiratory distress syndrome: from mechanism to translation. J Immunol. (2015) 194:855-60. doi: 10.4049/jimmunol.1402513

52. Hu X, Chakravarty SD, Ivashkiv LB. Regulation of interferon and toll-like receptor signaling during macrophage activation by opposing feedforward and feedback inhibition mechanisms. Immunol Rev. (2008) 226:41-56. doi: 10.1111/j.1600-065X.2008.00707.x

53. Risitano AM, Mastellos DC, Huber-Lang M, Yancopoulou D, Garlanda C, Ciceri F, et al. Complement as a target in COVID-19? Nat Rev Immunol. (2020) 20:343-4. doi: 10.1038/s41577-020-0320-7

54. Xu H, Zhong L, Deng J, Peng J, Dan H, Zeng X, et al. High expression of ACE2 receptor of 2019-nCoV on the epithelial cells of oral mucosa. Int $J$ Oral Sci. (2020) 12:1-5. doi: 10.1038/s41368-020-0074-x

55. Arentz M, Yim E, Klaff L, Lokhandwala S, Riedo FX, Chong M, et al. Characteristics and outcomes of 21 critically ill patients with COVID19 in Washington State. JAMA. (2020) 323:1612-4. doi: 10.1001/jama. 2020.4326

56. Chen N, Zhou M, Dong X, Qu J, Gong F, Han Y, et al. Epidemiological and clinical characteristics of 99 cases of 2019 novel coronavirus pneumonia in Wuhan, China: a descriptive study. Lancet. (2020) 395:507-13. doi: 10.1016/S0140-6736(20)30211-7

57. Wong SH, Lui RNS, Sung JJY. Covid-19 and the digestive system. J Gastroenterol Hepatol. (2020) 35:744-8. doi: 10.1111/jgh.15047 
58. Zhang C, Shi L, Wang FS. Liver injury in COVID-19: management and challenges. Lancet Gastroenterol Hepatol. (2020) 5:428-30. doi: 10.1016/S2468-1253(20)30057-1

59. Jin X, Lian JS, Hu JH, Gao J, Zheng L, Zhang YM, et al. Epidemiological, clinical and virological characteristics of 74 cases of coronavirus-infected disease 2019 (COVID-19) with gastrointestinal symptoms. Gut. (2020) 69:1002-9. doi: 10.1136/gutjnl-2020-320926

60. Zhou Z, Zhao N, Shu Y, Han S, Chen B, Shu X. Effect of gastrointestinal symptoms in patients with COVID-19. Gastroenterology. (2020) 158:2294-7. doi: $10.1053 /$ j.gastro.2020.03.020

61. Mao L, Jin H, Wang M, Hu Y, Chen S, He Q, et al. Neurologic manifestations of hospitalized patients with coronavirus disease 2019 in Wuhan, China. JAMA Neurol. (2020) 77:683-90. doi: 10.1001/jamaneurol.2020.1127

62. Varatharaj A, Thomas N, Ellul M, Davies NW, Pollak T, Tenorio EL, et al. UK-wide surveillance of neurological and neuropsychiatric complications of COVID-19: the first 153 patients. SSRN Electron J [Preprint]. (2020). doi: 10.2139/ssrn.3601761

63. Varga Z, Flammer AJ, Steiger P, Haberecker M, Andermatt R, Zinkernagel AS, et al. Endothelial cell infection and endotheliitis in COVID-19. Lancet. (2020) 395:1417-8. doi: 10.1016/S0140-6736(20)30937-5

64. Jacobs JL, Coyne CB. Mechanisms of MAVS regulation at the mitochondrial membrane. J Mol Biol. (2013) 425:5009-19. doi: 10.1016/j.jmb.2013.10.007

65. Rongvaux A. Innate immunity and tolerance toward mitochondria. Mitochondrion. (2018) 41:14-20. doi: 10.1016/j.mito.2017.10.007

66. Karan KR, Trumpff C, McGill MA, Thomas JE, Sturm G, Lauriola V, et al. Mitochondrial respiratory capacity modulates LPS-induced inflammatory signatures in human blood. Brain Behav Immun Heal. (2020) 5:1-12. doi: 10.1016/j.bbih.2020.100080

67. Kawai T, Akira S. Antiviral signaling through pattern recognition receptors. J Biochem. (2007) 141:137-45. doi: 10.1093/jb/mvm032

68. Gordon DE, Jang GM, Bouhaddou M, Xu J, Obernier K, White KM, et al. A SARS-CoV-2 protein interaction map reveals targets for drug repurposing. Nature. (2020) 583:459-68. doi: 10.1038/s41586-020-2286-9

69. Shi C-S, Qi H-Y, Boularan C, Huang N-N, Abu-Asab M, Shelhamer JH, et al. SARS-coronavirus open reading frame-9b suppresses innate immunity by targeting mitochondria and the MAVS/TRAF3/TRAF6 signalosome. $J$ Immunol. (2014) 193:3080-9. doi: 10.4049/jimmunol.1303196

70. Spiegel M, Pichlmair A, Martínez-Sobrido L, Cros J, García-Sastre A, Haller $\mathrm{O}$, et al. Inhibition of beta interferon induction by severe acute respiratory syndrome coronavirus suggests a two-step model for activation of interferon regulatory factor 3. J Virol. (2005) 79:2079-86. doi: 10.1128/jvi.79.4.2079-2086.2005

71. West AP, Khoury-Hanold W, Staron M, Tal MC, Pineda CM, Lang SM, et al. Mitochondrial DNA stress primes the antiviral innate immune response. Nature. (2015) 520:553-7. doi: 10.1038/nature14156

72. Arnoult D, Soares F, Tattoli I, Castanier C, Philipott D, Girardi ES. An Nterminal addressing sequence targets NLRX1 to the mitochondrial matrix. $J$ Cell Sci. (2009) 122:3161-8. doi: 10.1242/jcs.051193

73. Breda CN de S, Davanzo GG, Basso PJ, Saraiva Câmara NO, Moraes-Vieira PMM. Mitochondria as central hub of the immune system. Redox Biol. (2019) 26:101255. doi: 10.1016/j.redox.2019.101255

74. Fève B, Bastard J-P. The role of interleukins in insulin resistance and type 2 diabetes mellitus. Nat Rev Endocrinol. (2009) 5:305-11. doi: $10.1038 /$ nrendo.2009.62

75. Zhu L, She ZG, Cheng X, Qin JJ, Zhang XJ, Cai J, et al. Association of blood glucose control and outcomes in patients with COVID-19 and pre-existing type 2 diabetes. Cell Metab. (2020) 31:1068-77.e3. doi: 10.1016/j.cmet.2020.04.021

76. Codo AC, Davanzo GG, Monteiro L de B, de Souza GF, Muraro SP, Virgilioda-Silva JV, et al. Elevated glucose levels favor SARS-CoV-2 infection and monocyte response through a HIF- $1 \alpha /$ glycolysis-dependent axis. Cell Metab. (2020) 32:437-46.e5. doi: 10.1016/j.cmet.2020.07.007

77. Remels AHV, Derks WJA, Cillero-Pastor B, Verhees KJP, Kelders MC, Heggermont $\mathrm{W}$, et al. NF-кB-mediated metabolic remodelling in the inflamed heart in acute viral myocarditis. Biochim Biophys Acta Mol Basis Dis. (2018) 1864:2579-89. doi: 10.1016/j.bbadis.2018. 04.022
78. Al-Huseini I, Harada M, Nishi K, Nguyen-Tien D, Kimura T, Ashida $\mathrm{N}$. Improvement of insulin signalling rescues inflammatory cardiac dysfunction. Sci Rep. (2019) 9:1-13. doi: 10.1038/s41598-019-51304-8

79. Chen C, Zhou Y, Wang DW. SARS-CoV-2: a potential novel etiology of fulminant myocarditis. Herz. (2020) 45:230-2. doi: 10.1007/s00059-020-04909-z

80. Fried JA, Ramasubbu K, Bhatt R, Topkara VK, Clerkin KJ, Horn E, et al. The variety of cardiovascular presentations of COVID-19. Circulation. (2020) 141:1930-6. doi: 10.1161/CIRCULATIONAHA.120.047164

81. He J, Wu B, Chen Y, Tang J, Liu Q, Zhou S, et al. Characteristic electrocardiographic manifestations in patients with COVID-19. Can J Cardiol. (2020) 36:966.e1-e4. doi: 10.1016/j.cjca.2020.03.028

82. $\mathrm{Hu} \mathrm{H}, \mathrm{Ma} \mathrm{F}$, Wei X, Fang Y. Coronavirus fulminant myocarditis treated with glucocorticoid and human immunoglobulin. Eur Heart J. (2020) ehaa190. doi: 10.1093/eurheartj/ehaa190

83. Hua A, O'gallagher K, Sado D, Byrne J. Life-threatening cardiac tamponade complicating myo-pericarditis in COVID-19. Eur Heart J. (2020) 41:2130. doi: 10.1093/eurheartj/ehaa253

84. Inciardi RM, Lupi L, Zaccone G, Italia L, Raffo M, Tomasoni D, et al. Cardiac involvement in a patient with coronavirus disease 2019 (COVID-19). JAMA Cardiol. (2020) 5:819-24. doi: 10.1001/jamacardio.2020.1096

85. Tavazzi G, Pellegrini C, Maurelli M, Belliato M, Sciutti F, Bottazzi A, et al. Myocardial localization of coronavirus in COVID-19 cardiogenic shock. Eur J Heart Fail. (2020) 22:911-5. doi: 10.1002/ejhf.1828

86. Liu Y, Yang Y, Zhang C, Huang F, Wang F, Yuan J, et al. Clinical and biochemical indexes from 2019-nCoV infected patients linked to viral loads and lung injury. Sci China Life Sci. (2020) 63:364-74. doi: $10.1007 / \mathrm{s} 11427-020-1643-8$

87. Magro C, Mulvey JJ, Berlin D, Nuovo G, Salvatore S, Harp J, et al. Complement associated microvascular injury and thrombosis in the pathogenesis of severe COVID-19 infection: a report of five cases. Transl Res. (2020) 220:1-13. doi: 10.1016/j.trsl.2020.04.007

88. Middleton EA, He XY, Denorme F, Campbell RA, Ng D, Salvatore SP, et al. Neutrophil extracellular traps contribute to immunothrombosis in COVID-19 acute respiratory distress syndrome. Blood. (2020) 136:1169-79. doi: 10.1182/blood.2020007008

89. Li G, Fan Y, Lai Y, Han T, Li Z, Zhou P, et al. Coronavirus infections and immune responses. J Med Virol. (2020) 92:424-32. doi: 10.1002/jmv.25685

90. Warnatsch A, Ioannou M, Wang Q, Papayannopoulos V. Neutrophil extracellular traps license macrophages for cytokine production in atherosclerosis. Science. (2015) 349:316-20. doi: 10.1126/science.aaa8064

91. Barnes BJ, Adrover JM, Baxter-Stoltzfus A, Borczuk A, Cools-Lartigue J, Crawford JM, et al. Targeting potential drivers of COVID-19: neutrophil extracellular traps. J Exp Med. (2020) 217:e20200652. doi: 10.1084/jem.20200652

92. Mold C, Morris CA. Complement activation by apoptotic endothelial cells following hypoxia/reoxygenation. Immunology. (2001) 102:359-64. doi: 10.1046/j.1365-2567.2001.01192.x

93. Irabien-Ortiz Á, Carreras-Mora J, Sionis A, Pàmies J, Montiel J, Tauron M. Fulminant myocarditis due to COVID-19. Rev Española Cardiol (English Ed). (2020) 73:503-4. doi: 10.1016/j.rec.2020.04.005

94. Ackermann M, Verleden SE, Kuehnel M, Haverich A, Welte T, Laenger F, et al. Pulmonary vascular endothelialitis, thrombosis, and angiogenesis in Covid-19. N Engl J Med. (2020) 383:120-8. doi: 10.1056/NEJMoa2015432

95. Teuwen L-A, Geldhof V, Pasut A, Carmeliet P. COVID-19: the vasculature unleashed. Nat Rev Immunol. (2020) 20:389-91. doi: 10.1038/s41577-020-0343-0

96. Incalza MA, Perrini S. Oxidative stress and reactive oxygen species in endothelial dysfunction associated with cardiovascular and metabolic diseases. Vascul Pharmacol. (2017) 100:1-19. doi: 10.1016/j.vph.2017.05.005

97. Liu PP, Blet A, Smyth D, Li H. The science underlying COVID-19 implications for the cardiovascular system. Circulation. (2020) 142:68-78. doi: 10.1161/CIRCULATIONAHA.120.047549

98. Pober JS, Sessa WC. Evolving functions of endothelial cells in inflammation. Nat Rev Immunol. (2007) 7:803-15. doi: 10.1038/nri2171

99. Tang N, Bai H, Chen X, Gong J, Li D, Sun Z. Anticoagulant treatment is associated with decreased mortality in severe coronavirus disease 
2019 patients with coagulopathy. J Thromb Haemost. (2020) 18:1094-9. doi: $10.1111 /$ jth.14817

100. Paria BC, Vogel SM, Ahmmed GU, Alamgir S, Shroff J, Malik AB, et al. Tumor necrosis factor- $\alpha$-induced TRPC1 expression amplifies storeoperated $\mathrm{Ca}_{2}{ }^{+}$influx and endothelial permeability. Am J Physiol Lung Cell Mol Physiol. (2004) 287:1303-13. doi: 10.1152/ajplung.00240.2004

101. Vandenbroucke E, Mehta D, Minshall R, Malik AB. Regulation of endothelial junctional permeability. Ann N Y Acad Sci. (2008) 1123:134-45. doi: $10.1196 /$ annals. 1420.016

102. Sandoval R, Malik AB, Minshall RD, Kouklis P, Ellis CA, Tiruppathi C. $\mathrm{Ca}_{2}{ }^{+}$signalling and PKC $\alpha$ activate increased endothelial permeability by disassembly of VE-cadherin junctions. J Physiol. (2001) 533:433-45. doi: 10.1111/j.1469-7793.2001.0433a.x

103. Petrache I, Birukova A, Ramirez SI, Garcia JGN, Verin AD. The role of the microtubules in tumor necrosis factor-induced endothelial cell permeability. Am J Respir Cell Mol Biol. (2003) 28:574-81. doi: $10.1165 / \mathrm{rcmb} .2002-0075 \mathrm{OC}$

104. Tinsley JH, Hunter FA, Childs EW. PKC and MLCK-dependent, cytokineinduced rat coronary endothelial dysfunction. J Surg Res. (2009) 152:76-83. doi: $10.1016 /$ j.jss.2008.02.022

105. Wu Z, McGoogan JM. Characteristics of and important lessons from the coronavirus disease 2019 (COVID-19) outbreak in China: summary of a report of 72314 cases from the Chinese center for disease control and prevention. JAMA. (2020) 323:1239-42. doi: 10.1001/jama.2020.2648

106. Styp-Rekowska B, Hlushchuk R, Pries AR, Djonov V. Intussusceptive angiogenesis: pillars against the blood flow. Acta Physiol. (2011) 202:213-23. doi: $10.1111 / j .1748-1716.2011 .02321 . x$

107. Mentzer, SJ, Konerding, MA. Intussusceptive angiogenesis: expansion and remodeling of microvascular networks. Angiogenesis (2014) 17:499-509. doi: 10.1007/s10456-014-9428-3

108. Konerding MA, Turhan A, Ravnic DJ, Lin M, Fuchs C, Secomb TW, et al. Inflammation-induced intussusceptive angiogenesis in murine colitis. Anat Rec. (2010) 293:849-57. doi: 10.1002/ar.21110

109. Ackermann M, Stark H, Neubert L, Schubert S, Borchert P, Linz F, et al. Morphomolecular motifs of pulmonary neoangiogenesis in interstitial lung diseases. Eur Respir J. (2020) 55:1900933. doi: 10.1183/13993003.00933-2019

110. García-Ruiz C, Colell A, Marí M, Morales A, Fernández-Checa JC. Direct effect of ceramide on the mitochondrial electron transport chain leads to generation of reactive oxygen species: role of mitochondrial glutathione. $J$ Biol Chem. (1997) 272:11369-77. doi: 10.1074/jbc.272.17.11369

111. Zhang D, Yi F-X, Zou A-P, Li P-L. Role of ceramide in TNF- $\alpha-$ induced impairment of endothelium-dependent vasorelaxation in coronary arteries. Am J Physiol Circ Physiol. (2002) 283:H1785-94. doi: 10.1152/ajpheart.00318.2002

112. Frey RS, Rahman A, Kefer JC, Minshall RD, Malik AB. PKC $\zeta$ regulates TNF$\alpha$-induced activation of NADPH oxidase in endothelial cells. Circ Res. (2002) 90:1012-9. doi: 10.1161/01.RES.0000017631.28815.8E

113. Wu F, Schuster DP, Tyml K, Wilson JX. Ascorbate inhibits NADPH oxidase subunit p47phox expression in microvascular endothelial cells. Free Radic Biol Med. (2007) 42:124-31. doi: 10.1016/j.freeradbiomed.2006.10.033

114. Liaudet L, Vassalli G, Pacher P. Role of peroxynitrite in the redox regulation of cell signal transduction pathways. Front Biosci. (2009) 14:4809-14. doi: $10.2741 / 3569$

115. Radi R. Nitric Oxide, Oxidants, and Protein Tyrosine Nitration. (2004). Available online at: www.pnas.orgcgidoi10.1073pnas.0307446101 (accessed August 5, 2020).

116. Schulz E, Gori T, Münzel T. Oxidative stress and endothelial dysfunction in hypertension. Hypertens Res. (2011) 34:665-73. doi: 10.1038/hr.2011.39

117. Landmesser U, Spiekermann S, Dikalov S, Tatge H, Wilke R, Kohler C, et al. Vascular oxidative stress and endothelial dysfunction in patients with chronic heart failure. Circulation. (2002) 106:3073-8. doi: 10.1161/01.CIR.0000041431.57222.AF

118. Naik E, Dixit VM. Mitochondrial reactive oxygen species drive proinflammatory cytokine production. J Exp Med. (2011) 208:417-20. doi: $10.1084 /$ jem. 20110367

119. Browner NC, Sellak H, Lincoln TM. Downregulation of cGMPdependent protein kinase expression by inflammatory cytokines in vascular smooth muscle cells. Am J Physiol Cell Physiol. (2004) 287:88-96. doi: 10.1152/ajpcell.00039.2004.-NO

120. Hiroki J, Shimokawa H, Higashi M, Morikawa K, Kandabashi T, Kawamura $\mathrm{N}$, et al. Inflammatory stimuli upregulate Rho-kinase in human coronary vascular smooth muscle cells. J Mol Cell Cardiol. (2004) 37:537-46. doi: 10.1016/j.yjmcc.2004.05.008

121. Cheng H, Wang Y, Wang G. Organ-protective effect of angiotensinconverting enzyme 2 and its effect on the prognosis of COVID-19. J Med Virol. (2020) 92:726-30. doi: 10.1002/jmv.25785

122. Yan C, Yu H, Huang M, Li J, Zhang X, Han Y. Tumor necrosis factor$\alpha$ promote permeability of human umbilical vein endothelial cells via activating RhoA-ERK1/2 pathway. Zhonghua Xin Xue Guan Bing Za Zhi. (2011) 39:531-7.

123. Goshua G, Pine AB, Meizlish ML, Chang C, Zhang H, Bahel P, et al. Articles Endotheliopathy in COVID-19-associated coagulopathy: evidence from a single-centre, cross-sectional study. Lancet Haematol. (2020) 3026:18. doi: 10.1016/S2352-3026(20)30216-7

124. Orr AW, Hastings NE, Blackman BR, Wamhoff BR. Complex regulation and function of the inflammatory smooth muscle cell phenotype in atherosclerosis. J Vasc Res. (2010) 47:168-80. doi: 10.1159/000250095

125. Jung YD, Fan F, McConkey DJ, Jean ME, Liu W, Reinmuth N, et al. Role of P38 MAPK, AP-1, and NF-кb in interleukin-1 $\beta$-induced IL-8 expression in human vascular smooth muscle cells. Cytokine. (2002) 18:20613. doi: $10.1006 /$ cyto.2002.1034

126. Krown KA, Page MT, Nguyen C, Zechner D, Gutierrez V, Comstock KL, et al. Tumor necrosis factor alpha-induced apoptosis in cardiac myocytes: involvement of the sphingolipid signaling cascade in cardiac cell death. J Clin Invest. (1996) 98:2854-65. doi: 10.1172/JCI119114

127. Haudek SB, Taffet GE, Schneider MD, Mann DL. TNF provokes cardiomyocyte apoptosis and cardiac remodeling through activation of multiple cell death pathways. J Clin Invest. (2007) 117:2692-701. doi: 10.1172/JCI29134

128. Pulkki KJ. Cytokines and cardiomyocyte death. Ann Med. (1997) 29:339-43. doi: $10.3109 / 07853899708999358$

129. Frangogiannis NG. Inflammation in cardiac injury, repair and regeneration. Curr Opin Cardiol. (2015) 30:240-5. doi: 10.1097/HCO.0000000000000158

130. Prabhu SD, Frangogiannis NG. The biological basis for cardiac repair after myocardial infarction. Circ Res. (2016) 119:91-112. doi: 10.1161/CIRCRESAHA.116.303577

131. Bernardo ME, Fibbe WE. Mesenchymal stromal cells: sensors and switchers of inflammation. Cell Stem Cell. (2013) 13:392-402. doi: 10.1016/j.stem.2013.09.006

132. de Witte SFH, Luk F, Sierra Parraga JM, Gargesha M, Merino A, Korevaar SS, et al. Immunomodulation by therapeutic mesenchymal stromal cells (MSC) is triggered through phagocytosis of MSC by monocytic cells. Stem Cells. (2018) 36:602-15. doi: 10.1002/stem.2779

133. Leng Z, Zhu R, Hou W, Feng Y, Yang Y, Han Q, et al. Transplantation of ACE2- mesenchymal stem cells improves the outcome of patients with covid19 pneumonia. Aging Dis. (2020) 11:216-28. doi: 10.14336/AD.2020.0228

134. Chan MCW, Kuok DIT, Leung CYH, Hui KPY, Valkenburg SA, Lau EHY, et al. Human mesenchymal stromal cells reduce influenza A H5N1associated acute lung injury in vitro and in vivo. Proc Natl Acad Sci USA. (2016) 113:3621-6. doi: 10.1073/pnas.1601911113

135. Melief SM, Schrama E, Brugman MH, Tiemessen MM, Hoogduijn MJ, Fibbe WE, et al. Multipotent stromal cells induce human regulatory T cells through a novel pathway involving skewing of monocytes toward anti-inflammatory macrophages. Stem Cells. (2013) 31:1980-91. doi: 10.1002/stem.1432

136. Huh JW, Kim WY, Park YY, Lim CM, Koh Y, Kim MJ, et al. Antiinflammatory role of mesenchymal stem cells in an acute lung injury mouse model. Acute Crit Care. (2018) 33:154-61. doi: 10.4266/acc.2018.00619

137. Asami T, Ishii M, Namkoong H, Yagi K, Tasaka S, Asakura T, et al. Antiinflammatory roles of mesenchymal stromal cells during acute Streptococcus pneumoniae pulmonary infection in mice. Cytotherapy. (2018) 20:302-13. doi: 10.1016/j.jcyt.2018.01.003

138. Lee SH, Jang AS, Kim YE, Cha JY, Kim TH, Jung S, et al. Modulation of cytokine and nitric oxide by mesenchymal stem cell transfer in lung injury/fibrosis. Respir Res. (2010) 11:16. doi: 10.1186/1465-9921-11-16 
139. Khedoe PPSJ, de Kleijn S, van Oeveren-Rietdijk AM, Plomp JJ, de Boer HC, van Pel M, et al. Acute and chronic effects of treatment with mesenchymal stromal cells on LPS-induced pulmonary inflammation, emphysema and atherosclerosis development. PLoS ONE. (2017) 12:e0183741. doi: 10.1371/journal.pone.0183741

140. Geng Y, Zhang L, Fu B, Zhang J, Hong Q, Hu J, et al. Mesenchymal stem cells ameliorate rhabdomyolysis-induced acute kidney injury via the activation of M2 macrophages. Stem Cell Res Ther. (2014) 5:80. doi: 10.1186/scrt469

141. Li S, Zheng X, Li H, Zheng J, Chen X, Liu W, et al. Mesenchymal stem cells ameliorate hepatic ischemia/reperfusion injury via inhibition of neutrophil recruitment. J Immunol Res. (2018) 2018:1-10. doi: 10.1155/2018/7283703

142. Espinosa G, Plaza A, Schenffeldt A, Alarcón P, Gajardo G, Uberti B, et al. Equine bone marrow-derived mesenchymal stromal cells inhibit reactive oxygen species production by neutrophils. Vet Immunol Immunopathol. (2020) 221:109975. doi: 10.1016/j.vetimm.2019.109975

143. Jiang D, Muschhammer J, Qi Y, Kügler A, de Vries JC, Saffarzadeh $\mathrm{M}$, et al. Suppression of neutrophil-mediated tissue damage-a novel skill of mesenchymal stem cells. Stem Cells. (2016) 34:2393-406. doi: 10.1002/stem.2417

144. Hashmi S, Ahmed M, Murad MH, Litzow MR, Adams RH, Ball LM, et al. Survival after mesenchymal stromal cell therapy in steroid-refractory acute graft-versus-host disease: systematic review and meta-analysis. Lancet Haematol. (2016) 3:e45-52. doi: 10.1016/S2352-3026(15)00224-0

145. Sala E, Genua M, Petti L, Anselmo A, Arena V, Cibella J, et al. Mesenchymal stem cells reduce colitis in mice via release of TSG6, independently of their localization to the intestine. Gastroenterology. (2015) 149:163-76.e20. doi: 10.1053/j.gastro.2015.03.013

146. Song HB, Park SY, Ko JH, Park JW, Yoon CH, Kim DH, et al. Mesenchymal stromal cells inhibit inflammatory lymphangiogenesis in the cornea by suppressing macrophage in a TSG-6-dependent manner. Mol Ther. (2018) 26:162-72. doi: 10.1016/j.ymthe.2017.09.026

147. Wang G, Cao K, Liu K, Xue Y, Roberts AI, Li F, et al. Kynurenic acid, an IDO metabolite, controls TSG-6-mediated immunosuppression of human mesenchymal stem cells. Cell Death Differ. (2018) 25:1209-23. doi: 10.1038/s41418-017-0006-2

148. Tjabringa GS, Zandieh-Doulabi B, Helder MN, Knippenberg M, Wuisman PIJM, Klein-Nulend J. The polymine spermine regulates osteogenic differentiation in adipose stem cells. J Cell Mol Med. (2008) 12:1710-7. doi: 10.1111/j.1582-4934.2008.00224.x

149. Yang Q, Zheng C, Cao J, Cao G, Shou P, Lin L, et al. Spermidine alleviates experimental autoimmune encephalomyelitis through inducing inhibitory macrophages. Cell Death Differ. (2016) 23:1850-61. doi: 10.1038/cdd.2016.71

150. Selleri S, Bifsha P, Civini S, Pacelli C, Dieng MM, Lemieux W, et al. Human mesenchymal stromal cell-secreted lactate induces M2-macrophage differentiation by metabolic reprogramming. Oncotarget. (2016) 7:30193210. doi: 10.18632/oncotarget.8623

151. Groh ME, Maitra B, Szekely E, Koç ON. Human mesenchymal stem cells require monocyte-mediated activation to suppress alloreactive T cells. Exp Hematol. (2005) 33:928-34. doi: 10.1016/j.exphem.2005.05.002

152. Corcione A, Benvenuto F, Ferretti E, Giunti D, Cappiello V, Cazzanti F, et al. Human mesenchymal stem cells modulate B-cell functions. Blood. (2006) 107:367-72. doi: 10.1182/blood-2005-07-2657

153. Peng Y, Chen X, Liu Q, Zhang X, Huang K, Liu L, et al. Mesenchymal stromal cells infusions improve refractory chronic graft versus host disease through an increase of $\mathrm{CD}^{+}$regulatory B cells producing interleukin 10. Leukemia. (2015) 29:636-46. doi: 10.1038/leu.2014.225

154. Zhu Y, Wang Y, Zhao B, Niu X, Hu B, Li Q, et al. Comparison of exosomes secreted by induced pluripotent stem cell-derived mesenchymal stem cells and synovial membrane-derived mesenchymal stem cells for the treatment of osteoarthritis. Stem Cell Res The.r. (2017) 8:64. doi: 10.1186/s13287-017-0510-9

155. Dabrowska S, Andrzejewska A, Strzemecki D, Muraca M, Janowski M, Lukomska B. Human bone marrow mesenchymal stem cellderived extracellular vesicles attenuate neuroinflammation evoked by focal brain injury in rats. J Neuroinflammation. (2019) 16:1-15. doi: 10.1186/s12974-019-1602-5

156. Shi Y, Wang Y, Li Q, Liu K, Hou J, Shao C, et al. Immunoregulatory mechanisms of mesenchymal stem and stromal cells in inflammatory diseases. Nat Rev Nephrol. (2018) 14:493-507. doi: 10.1038/s41581-018-0023-5

157. Huppert LA, Matthay MA. Alveolar fluid clearance in pathologically relevant conditions: in vitro and in vivo models of acute respiratory distress syndrome. Front Immunol. (2017) 8:371. doi: 10.3389/fimmu.2017.00371

158. Simonson OE, Mougiakakos D, Heldring N, Bassi G, Johansson HJ, Dalén $\mathrm{M}$, et al. In vivo effects of mesenchymal stromal cells in two patients with severe acute respiratory distress syndrome. Stem Cells Transl Med. (2015) 4:1199-213. doi: 10.5966/sctm.2015-0021

159. Horie S, Gonzalez HE, Laffey JG, Masterson CH. Cell therapy in acute respiratory distress syndrome. J Thorac Dis. (2018) 10:5607-20. doi: $10.21037 /$ jtd.2018.08.28

160. Xiao K, Hou F, Huang X, Li B, Qian ZR, Xie L. Mesenchymal stem cells: current clinical progress in ARDS and COVID-19. Stem Cell Res Ther. (2020) 11:305. doi: 10.1186/s13287-020-01804-6

161. Liang B, Chen J, Li T, Wu H, Yang W, Li Y, Li J, Yu C, Nie F, Ma Z, et al. Clinical remission of a critically ill COVID-19 patient treated by human umbilical cord mesenchymal stem cells. Medicine. (2020) 99:e21429. doi: 10.1097/MD.0000000000021429

162. Zhang Y, Ding J, Ren S, Wang W, Yang Y, Li S, et al. Intravenous infusion of human umbilical cord Wharton's jelly-derived mesenchymal stem cells as a potential treatment for patients with COVID-19 pneumonia. Stem Cell Res Ther. (2020) 11:207. doi: 10.1186/s13287-020-01725-4

163. Chen J, Hu C, Chen L, Tang L, Zhu Y, Xu X, et al. Clinical study of mesenchymal stem cell treatment for acute respiratory distress syndrome induced by epidemic influenza A (H7N9) infection: a hint for COVID-19 treatment. Engineering. (in press). doi: 10.1016/j.eng.2020.02.006

164. Sengupta V, Sengupta S, Lazo A, Woods P, Nolan A, Bremer N. Exosomes derived from bone marrow mesenchymal stem cells as treatment for severe COVID-19. Stem Cells Dev. (2020) 29:747-54. doi: 10.1089/scd. 2020.0080

165. Moll G, Drzeniek N, Kamhieh-Milz J, Geissler S, Volk H-D, Reinke P. MSC therapies for COVID-19: importance of patient coagulopathy, thromboprophylaxis, cell product quality and mode of delivery for treatment safety and efficacy. Front Immunol. (2020) 11:1091. doi: 10.3389/fimmu.2020.01091

166. Can A, Coskun $H$. The rationale of using mesenchymal stem cells in patients with COVID-19-related acute respiratory distress syndrome: what to expect. Stem Cells Transl Med. (2020) 9:sctm.20-0164. doi: 10.1002/sctm.20-0164

167. Peng H, Gong T, Huang X, Sun X, Luo H, Wang W, et al. A synergistic role of convalescent plasma and mesenchymal stem cells in the treatment of severely ill COVID-19 patients: a clinical case report. Stem Cell Res Ther. (2020) 291:1-6. doi: 10.1186/s13287-020-01802-8

168. Lippi G, Lavie CJ, Sanchis-Gomar F. Cardiac troponin I in patients with coronavirus disease 2019 (COVID-19): evidence from a meta-analysis. Prog Cardiovasc Dis. (2020) 63:390-1. doi: 10.1016/j.pcad.2020.03.001

169. Wei JF, Huang FY, Xiong TY, Liu Q, Chen H, Wang H, et al. Acute myocardial injury is common in patients with COVID-19 and impairs their prognosis. Heart. (2020) 106:1154-9. doi: 10.1136/heartjnl-2020-317007

170. Du RH, Liang LR, Yang CQ, Wang W, Cao TZ, Li M, et al. Predictors of mortality for patients with COVID-19 pneumonia caused by SARSCoV- 2: a prospective cohort study. Eur Respir J. (2020) 55:2000524. doi: 10.1183/13993003.00524-2020

171. Bangalore S, Sharma A, Slotwiner A, Yatskar L, Harari R, Shah B, et al. STsegment elevation in patients with covid-19-a case series. $N$ Engl J Med. (2020) 382:2478-80. doi: 10.1056/NEJMc2009020

172. Lodigiani C, Iapichino G, Carenzo L, Cecconi M, Ferrazzi P, Sebastian T, et al. Venous and arterial thromboembolic complications in COVID-19 patients admitted to an academic hospital in Milan, Italy. Thromb Res. (2020) 191:9-14. doi: 10.1016/j.thromres.2020.04.024

173. Klok FA, Kruip MJHA, van der Meer NJM, Arbous MS, Gommers DAMPJ, Kant KM, et al. Incidence of thrombotic complications in critically ill ICU patients with COVID-19. Thromb Res. (2020) 191:145-7. doi: 10.1016/j.thromres.2020.04.013

174. Zhu H, Song X, Jin LY, Jin P, Guan R, Liu X, et al. Comparison of intracoronary cell transplantation after myocardial infarction: autologous skeletal myoblasts versus bone marrow mesenchymal stem cells. J Int Med Res. (2009) 37:298-307. doi: 10.1177/147323000903700203 
175. Chen SL, Fang WW, Ye F, Liu YH, Qian J, Shan SJ, et al. Effect on left ventricular function of intracoronary transplantation of autologous bone marrow mesenchymal stem cell in patients with acute myocardial infarction. Am J Cardio.l. (2004) 94:92-5. doi: 10.1016/j.amjcard.2004. 03.034

176. Chin SP, Poey AC, Wong CY, Chang SK, Tan CS, Ng MT, et al. Intramyocardial and intracoronary autologous bone marrow-derived mesenchymal stromal cell treatment in chronic severe dilated cardiomyopathy. Cytotherapy. (2011) 13:814-21. doi: 10.3109/14653249.2011.574118

177. Lu M, Liu S, Zheng Z, Yin G, Song L, Chen H, et al. A pilot trial of autologous bone marrow mononuclear cell transplantation through grafting artery: a sub-study focused on segmental left ventricular function recovery and scar reduction. Int J Cardiol. (2013) 168:2221-7. doi: 10.1016/j.ijcard.2013.01.217

178. Premer C, Blum A, Bellio MA, Schulman IH, Hurwitz BE, Parker M, et al. Allogeneic mesenchymal stem cells restore endothelial function in heart failure by stimulating endothelial progenitor cells. EBioMedicine. (2015) 2:467-75. doi: 10.1016/j.ebiom.2015.03.020

179. Rodrigo SF, Van Ramshorst J, Hoogslag GE, Boden H, Velders MA, Cannegieter SC, et al. Intramyocardial injection of autologous bone marrowderived Ex vivo expanded mesenchymal stem cells in acute myocardial infarction patients is feasible and safe up to 5 years of follow-up. J Cardiovasc Transl Res. (2013) 6:816-25. doi: 10.1007/s12265-013-9507-7

180. Heldman AW, DiFede DL, Fishman JE, Zambrano JP, Trachtenberg $\mathrm{BH}$, Karantalis V, et al. Transendocardial mesenchymal stem cells and mononuclear bone marrow cells for ischemic cardiomyopathy: the TAC-HFT randomized trial. JAMA. (2014) 311:62-73. doi: 10.1001/jama.2013.282909

181. Anastasiadis K, Antonitsis P, Westaby S, Reginald A, Sultan S, Doumas $A$, et al. Implantation of a novel allogeneic mesenchymal precursor cell type in patients with ischemic cardiomyopathy undergoing coronary artery bypass grafting: an open label phase iia trial. J Cardiovasc Transl Res. (2016) 9:202-13. doi: 10.1007/s12265-016-9686-0

182. Florea V, Rieger AC, DiFede DL, El-Khorazaty J, Natsumeda M, Banerjee $\mathrm{MN}$, et al. Dose comparison study of allogeneic mesenchymal stem cells in patients with ischemic cardiomyopathy (The TRIDENT study). Circ Res. (2017) 121:1279-90. doi: 10.1161/CIRCRESAHA.117.311827

183. Chullikana A, Majumdar A Sen, Gottipamula S, Krishnamurthy S, Kumar AS, Prakash VS, et al. Randomized, double-blind, phase I/II study of intravenous allogeneic mesenchymal stromal cells in acute myocardial infarction. Cytotherapy. (2015) 17:250-61. doi: 10.1016/j.jcyt.2014.10.009

184. Hare JM, Traverse JH, Henry TD, Dib N, Strumpf RK, Schulman SP, et al. A randomized, double-blind, placebo-controlled, dose-escalation study of intravenous adult human mesenchymal stem cells (prochymal) after acute myocardial infarction. J Am Coll Cardiol. (2009) 54:2277-86. doi: 10.1016/j.jacc.2009.06.055

185. Cai B, Wang G, Chen N, Liu Y, Yin K, Ning C, et al. Bone marrow mesenchymal stem cells protected post-infarcted myocardium against arrhythmias via reversing potassium channels remodelling. J Cell $\mathrm{Mol} \mathrm{Med.}$ (2014) 18:1407-16. doi: 10.1111/jcmm.12287

186. Zhang S, Ge J, Sun A, Xu D, Qian J, Lin J, al. Comparison of various kinds of bone marrow stem cells for the repair of infarcted myocardium: single clonally purified non-hematopoietic mesenchymal stem cells serve as a superior source. J Cell Biochem. (2006) 99:1132-47. doi: 10.1002/jcb.20949

187. Haider HK, Jiang S, Idris NM, Ashraf M. IGF-1-overexpressing mesenchymal stem cells accelerate bone marrow stem cell mobilization via paracrine activation of SDF-1 $\alpha /$ CXCR 4 signaling to promote myocardial repair. Circ Res. (2008) 103:1300-8. doi: 10.1161/CIRCRESAHA.108.186742

188. Herrmann JL, Abarbanell AM, Weil BR, Wang Y, Poynter JA, Manukyan $\mathrm{MC}$, et al. Postinfarct intramyocardial injection of mesenchymal stem cells pretreated with TGF- $\alpha$ improves acute myocardial function. Am J Physiol Integr Comp Physiol. (2010) 299:R371-8. doi: 10.1152/ajpregu.000 84.2010

189. Beitnes JO, Øie E, Shahdadfar A, Karlsen T, Müller RMB, Aakhus $S$, et al. Intramyocardial injections of human mesenchymal stem cells following acute myocardial infarction modulate scar formation and improve left ventricular function. Cell Transplant. (2012) 21:1697-709. doi: $10.3727 / 096368911 \times 627462$
190. Chen L, Zhang Y, Tao L, Yang Z, Wang L. Mesenchymal stem cells with eNOS over-expression enhance cardiac repair in rats with myocardial infarction. Cardiovasc Diagn Ther. (2017) 31:9-18. doi: 10.1007/s10557-016-6704-Z

191. Czapla J, Matuszczak S, Wiśniewska E, Jarosz-Biej M, Smolarczyk R, Cichoń $\mathrm{T}$, et al. Human cardiac mesenchymal stromal cells with $\mathrm{CD} 105^{+} \mathrm{CD} 34^{-}$ phenotype enhance the function of post-infarction heart in mice. PLOS ONE. (2016) 11:e0158745. doi: 10.1371/journal.pone.0158745

192. Shyu K-G, Wang B-W, Hung H-F, Chang C-C, Tzu-Bi Shih D. Mesenchymal stem cells are superior to angiogenic growth factor genes for improving myocardial performance in the mouse model of acute myocardial infarction. J Biomed Sci. (2006) 13:47-58. doi: 10.1007/s11373-0059038-6

193. Zhang J, Wu Y, Chen A, Zhao Q. Mesenchymal stem cells promote cardiac muscle repair via enhanced neovascularization. Cell Physiol Biochem. (2015) 35:1219-29. doi: 10.1159/000373945

194. Ellison GM, Nadal-Ginard B, Torella D. Optimizing cardiac repair and regeneration through activation of the endogenous cardiac stem cell compartment. J Cardiovasc Transl Res. (2012) 5:667-77. doi: 10.1007/s12265-012-9384-5

195. Dai W, Hale SL, Kloner RA. Role of a paracrine action of mesenchymal stem cells in the improvement of left ventricular function after coronary artery occlusion in rats. Regen Med. (2007) 2:63-8. doi: 10.2217/17460751.2.1.63

196. De Macedo Braga LMG, Lacchini S, Schaan BDA, Rodrigues B, Rosa $\mathrm{K}$, De Angelis $\mathrm{K}$, et al. In situ delivery of bone marrow cells and mesenchymal stem cells improves cardiovascular function in hypertensive rats submitted to myocardial infarction. J Biomed Sci. (2008) 15:365-74. doi: $10.1007 /$ s11373-008-9237-z

197. Van Der Spoel TIG, Jansen Of Lorkeers SJ, Agostoni P, Van Belle E, Gyongyosi M, Sluijter JPG, et al. Human relevance of pre-clinical studies in stem cell therapy: systematic review and meta-analysis of large animal models of ischaemic heart disease. Cardiovasc Res. (2011) 91:649-58. doi: $10.1093 / \mathrm{cvr} / \mathrm{cvr} 113$

198. Natsumeda M, Florea V, Rieger AC, Tompkins BA, Banerjee $\mathrm{MN}$, Golpanian S, et al. A combination of allogeneic stem cells promotes cardiac regeneration. J Am Coll Cardiol. (2017) 70:2504-15. doi: 10.1016/j.jacc.2017.09.036

199. Karantalis V, Suncion-Loescher VY, Bagno L, Golpanian S, Wolf A, Sanina C, et al. Synergistic effects of combined cell therapy for chronic ischemic cardiomyopathy. J Am Coll Cardiol. (2015) 66:1990-9. doi: 10.1016/j.jacc.2015.08.879

200. Lee JW, Lee SH, Youn YJ, Ahn MS, Kim JY, Yoo BS, et al. A randomized, open-label, multicenter trial for the safety and efficacy of adult mesenchymal stem cells after acute myocardial infarction. J Korean Med Sci. (2014) 29:2331. doi: 10.3346/jkms.2014.29.1.23

201. Qi Z, Duan F, Liu S, Lv X, Wang H, Gao Y, et al. Effects of bone marrow mononuclear cells delivered through a graft vessel for patients with previous myocardial infarction and chronic heart failure: an echocardiographic study of left ventricular function. Echocardiography. (2015) 32:937-46. doi: $10.1111 /$ echo.12787

202. Kim SH, Cho JH, Lee YH, Lee JH, Kim SS, Kim MY, et al. Improvement in left ventricular function with intracoronary mesenchymal stem cell therapy in a patient with anterior wall ST-segment elevation myocardial infarction. Cardiovasc Drugs Ther. (2018) 32:329-38. doi: 10.1007/s10557-018-6804-z

203. Chen S, Fang W, Qian J, YE F, Liu Y, Shan S, et al. Improvement of cardiac function after transplantation of autologous bone marrow mesenchymal stem cells in patients with acute myocardial infarction. Chin Med J (Engl). (2004) 117:1443-8.

204. Penn MS, Ellis S, Gandhi S, Greenbaum A, Hodes Z, Mendelsohn FO, et al. Adventitial delivery of an allogeneic bone marrow-derived adherent stem cell in acute myocardial infarction: phase i clinical study. Circ Res. (2012) 110:304-11. doi: 10.1161/CIRCRESAHA.111.253427

205. Wang X, Xi W-C, Wang F. The beneficial effects of intracoronary autologous bone marrow stem cell transfer as an adjunct to percutaneous coronary intervention in patients with acute myocardial infarction. Biotechnol Lett. (2014) 36:2163-8. doi: 10.1007/s10529-014-1589-z

206. Gao LR, Pei XT, Ding QA, Chen Y, Zhang NK, Chen HY, et al. A critical challenge: dosage-related efficacy and acute complication intracoronary injection of autologous bone marrow mesenchymal stem 
cells in acute myocardial infarction. Int J Cardiol. (2013) 168:3191-9. doi: 10.1016/j.ijcard.2013.04.112

207. Yang Z, Zhang F, Ma W, Chen B, Zhou F, Xu Z, et al. A novel approach to transplanting bone marrow stem cells to repair human myocardial infarction: delivery via a noninfarct-relative artery. Cardiovasc Ther. (2010) 28:380-5. doi: 10.1111/j.1755-5922.2009.00116.x

208. Scalise M, Torella M, Marino F, Ravo M, Giurato G, Vicinanza C, et al. Atrial myxomas arise from multipotent cardiac stem cells. Eur Heart J. (2020) ehaa156. doi: 10.1093/eurheartj/ehaa156

209. Vicinanza C, Aquila I, Scalise M, Cristiano F, Marino F, Cianflone E, et al. Adult cardiac stem cells are multipotent and robustly myogenic: C-kit expression is necessary but not sufficient for their identification. Cell Death Differ. (2017) 24:2101-16. doi: 10.1038/cdd.2017.130

210. Lewis-McDougall FC, Ruchaya PJ, Domenjo-Vila E, Shin Teoh T, Prata L, Cottle BJ, et al. Aged-senescent cells contribute to impaired heart regeneration. Aging Cell. (2019) 18:1-15. doi: 10.1111/acel.12931

211. Ellison-Hughes GM, Madeddu P. Exploring pericyte and cardiac stem cell secretome unveils new tactics for drug discovery. Pharmacol Ther. (2017) 171:1-12. doi: 10.1016/j.pharmthera.2016.11.007

212. Zhu M, Chu Y, Shang Q, Zheng Z, Li Y, Cao L, et al. Mesenchymal stromal cells pretreated with pro-inflammatory cytokines promote skin wound healing through VEGFC-mediated angiogenesis. Stem Cells Transl Med. (2020) 9:1218-32. doi: 10.1002/sctm.19-0241

213. Miyahara Y, Nagaya N, Kataoka M, Yanagawa B, Tanaka K, Hao H, et al. Monolayered mesenchymal stem cells repair scarred myocardium after myocardial infarction. Nat Med. (2006) 12:459-65. doi: 10.1038/nm1391

214. Qian D, Gong J, He Z, Hua J, Lin S, Xu C, et al. Bone marrowderived mesenchymal stem cells repair necrotic pancreatic tissue and promote angiogenesis by secreting cellular growth factors involved in the SDF-1 /CXCR4 axis in rats. Stem Cells Int. (2015) 2015:1-20. doi: 10.1155/2015/306836

215. Teng X, Chen L, Chen W, Yang J, Yang Z, Shen Z. Mesenchymal stem cellderived exosomes improve the microenvironment of infarcted myocardium contributing to angiogenesis and anti-inflammation. Cell Physiol Biochem. (2015) 37:2415-24. doi: 10.1159/000438594

216. Huang NF, Lam A, Fang Q, Sievers RE, Li S, Lee RJ. Bone marrow-derived mesenchymal stem cells in fibrin augment angiogenesis in the chronically infarcted myocardium. Regen Med. (2009) 4:527-38. doi: 10.2217/rme.09.32

217. Cai M, Ren L, Xiaoqin Y, Guo Z, Li Y, He T, et al. PET monitoring angiogenesis of infarcted myocardium after treatment with vascular endothelial growth factor and bone marrow mesenchymal stem cells. Amino Acids. (2016) 48:811-20. doi: 10.1007/s00726-015-2129-4

218. Carrion B, Kong YP, Kaigler D, Putnam AJ. Bone marrow-derived mesenchymal stem cells enhance angiogenesis via their $\alpha 6 \beta 1$ integrin receptor. Exp Cell Res. (2013) 319:2964-76. doi: 10.1016/j.yexcr.2013. 09.007

219. Du WJ, Chi Y, Yang ZX, Li ZJ, Cui JJ, Song BQ, et al. Heterogeneity of proangiogenic features in mesenchymal stem cells derived from bone marrow, adipose tissue, umbilical cord, and placenta. Stem Cell Res Ther. (2016) 7:1-11. doi: 10.1186/s13287-016-0418-9

220. Gangadaran P, Rajendran RL, Lee HW, Kalimuthu S, Hong CM, Jeong SY, et al. Extracellular vesicles from mesenchymal stem cells activates VEGF receptors and accelerates recovery of hindlimb ischemia. J Control Release. (2017) 264:112-26. doi: 10.1016/j.jconrel.2017.08.022

221. Huang B, Qian J, Ma J, Huang Z, Shen Y, Chen X, et al. Myocardial transfection of hypoxia-inducible factor- $1 \alpha$ and co-transplantation of mesenchymal stem cells enhance cardiac repair in rats with experimental myocardial infarction. Stem Cell Res Ther. (2014) 5:22. doi: 10.1186/scrt410

222. Kwon HM, Hur SM, Park KY, Kim CK, Kim YM, Kim HS, et al. Multiple paracrine factors secreted by mesenchymal stem cells contribute to angiogenesis. Vascul Pharmacol. (2014) 63:19-28. doi: 10.1016/j.vph.2014.06.004

223. Kehl D, Generali M, Mallone A, Heller M, Uldry AC, Cheng P, et al. Proteomic analysis of human mesenchymal stromal cell secretomes: a systematic comparison of the angiogenic potential. npj Regen Med. (2019) 4:1-13. doi: 10.1038/s41536-019-0070-y

224. Liu L, Gao J, Yuan Y, Chang Q, Liao Y, Lu F. Hypoxia preconditioned human adipose derived mesenchymal stem cells enhance angiogenic potential via secretion of increased VEGF and bFGF. Cell Biol Int. (2013) 37:551-60. doi: $10.1002 /$ cbin. 10097

225. Anderson JD, Johansson HJ, Graham CS, Vesterlund M, Pham MT, Bramlett CS, et al. Comprehensive proteomic analysis of mesenchymal stem cell exosomes reveals modulation of angiogenesis via nuclear factor-kappaB signaling. Stem Cells. (2016) 34:601-13. doi: 10.1002/stem.2298

226. Zhang Z, Yang J, Yan W, Li Y, Shen Z, Asahara T. Pretreatment of cardiac stem cells with exosomes derived from mesenchymal stem cells enhances myocardial repair. J Am Heart Assoc. (2016) 5:e002856. doi: 10.1161/JAHA.115.002856

227. Hanna H, Mir LM, Andre FM. In vitro osteoblastic differentiation of mesenchymal stem cells generates cell layers with distinct properties. Stem Cell Res Ther. (2018) 9:203. doi: 10.1186/s13287-018-0942-x

228. Takeda YS, Xu Q. Neuronal differentiation of human mesenchymal stem cells using exosomes derived from differentiating neuronal cells. PLOS ONE. (2015) 10:e0135111. doi: 10.1371/journal.pone.0135111

229. Xie X, Wang J, Cao J, Zhang X. Differentiation of bone marrow mesenchymal stem cells induced by myocardial medium under hypoxic conditions. Acta Pharmacol Sin. (2006) 27:1153-8. doi: 10.1111/j.1745-7254.2006.00436.x

230. Choi J-W, Kim K-E, Lee CY, Lee J, Seo H-H, Lim KH, et al. Alterations in cardiomyocyte differentiation-related proteins in rat mesenchymal stem cells exposed to hypoxia. Cell Physiol Biochem. (2016) 39:1595-607. doi: $10.1159 / 000447861$

231. Noiseux N, Gnecchi M, Lopez-Ilasaca M, Zhang L, Solomon SD, Deb A, et al. Mesenchymal stem cells overexpressing Akt dramatically repair infarcted myocardium and improve cardiac function despite infrequent cellular fusion or differentiation. Mol Ther. (2006) 14:840-50. doi: 10.1016/j.ymthe.2006.05.016

232. Derval N, Barandon L, Dufourcq P, Leroux L, Lamazière J-MD, Daret D, et al. Epicardial deposition of endothelial progenitor and mesenchymal stem cells in a coated muscle patch after myocardial infarction in a murine model. Eur J Cardio-Thoracic Surg. (2008) 34:248-54. doi: 10.1016/j.ejcts.2008.03.058

233. Wu S-Z, Li Y-L, Huang W, Cai W-F, Liang J, Paul C, et al. Paracrine effect of CXCR4-overexpressing mesenchymal stem cells on ischemic heart injury. Cell Biochem Funct. (2017) 35:113-23. doi: 10.1002/cbf.3254

234. Yao Z, Liu H, Yang M, Bai Y, Zhang B, Wang C, et al. Bone marrow mesenchymal stem cell-derived endothelial cells increase capillary density and accelerate angiogenesis in mouse hindlimb ischemia model. Stem Cell Res Ther. (2020) 11:221. doi: 10.1186/s13287-020-01710-x

235. Nascimento DS, Mosqueira D, Sousa LM, Teixeira M, Filipe M, Resende $\mathrm{TP}$, et al. Human umbilical cord tissue-derived mesenchymal stromal cells attenuate remodeling after myocardial infarction by proangiogenic, antiapoptotic, and endogenous cell-activation mechanisms. Stem Cell Res The.r. (2014) 5:1-14. doi: 10.1186/scrt394

236. Kang K, Ma R, Cai W, Huang W, Paul C, Liang J, et al. Exosomes secreted from CXCR4 overexpressing mesenchymal stem cells promote cardioprotection via akt signaling pathway following myocardial infarction. Stem Cells Int. (2015) 2015:1-14. doi: 10.1155/2015/659890

237. Li X, Xie X, Yu Z, Chen Y, Qu G, Yu H, et al. Bone marrow mesenchymal stem cells-derived conditioned medium protects cardiomyocytes from hypoxia/reoxygenation-induced injury through Notch2/mTOR/autophagy signaling. J Cell Physiol. (2019) 234:18906-16. doi: 10.1002/jcp.28530

238. Li H, Zuo S, He Z, Yang Y, Pasha Z, Wang Y, et al. Paracrine factors released by GATA-4 overexpressed mesenchymal stem cells increase angiogenesis and cell survival. Am J Physiol Hear Circ Physiol. (2010) 299:1772-81. doi: 10.1152/ajpheart.00557.2010.-Transplanted

239. Zhang D, Fan GC, Zhou X, Zhao T, Pasha Z, Xu M, et al. Overexpression of CXCR4 on mesenchymal stem cells augments myoangiogenesis in the infarcted myocardium. J Mol Cell Cardiol. (2008) 44:281-92. doi: $10.1016 /$ j.yjmcc.2007.11.010

240. Kawaguchi N, Smith AJ, Waring CD, Hasan K, Miyamoto S, Matsuoka R, et al. c-kit pos GATA-4 high rat cardiac stem cells foster adult cardiomyocyte survival through IGF-1 paracrine signalling. PLoS ONE. (2010) 5:e14297. doi: 10.1371/journal.pone.0014297

241. Yamaguchi J-i, Kusano KF, Masuo O, Kawamoto A, Silver M, Murasawa S, et al. Stromal cell-derived factor-1 effects on ex vivo expanded endothelial progenitor cell recruitment for ischemic neovascularization. Circulation. (2003) 107:1322-8. doi: 10.1161/01.CIR.0000055313.77510.22 
242. Ceradini DJ, Kulkarni AR, Callaghan MJ, Tepper OM, Bastidas N, Kleinman ME, et al. Progenitor cell trafficking is regulated by hypoxic gradients through HIF-1 induction of SDF-1. Nat Med. (2004) 10:858-64. doi: $10.1038 / \mathrm{nm} 1075$

243. De Falco E, Porcelli D, Torella AR, Straino S, Iachininoto MG, Orlandi A, et al. SDF-1 involvement in endothelial phenotype and ischemia-induced recruitment of bone marrow progenitor cells. Blood. (2004) 104:3472-82. doi: 10.1182/blood-2003-12-4423

244. Luger D, Lipinski MJ, Westman PC, Glover DK, Dimastromatteo J, Frias JC, et al. Intravenously delivered mesenchymal stem cells. Circ Res. (2017) 120:1598-613. doi: 10.1161/CIRCRESAHA.117.310599

245. Yan X, Anzai A, Katsumata Y, Matsuhashi T, Ito K, Endo J, et al. Temporal dynamics of cardiac immune cell accumulation following acute myocardial infarction. J Mol Cell Cardiol. (2013) 62:24-35. doi: 10.1016/j.yjmcc.2013.04.023

246. Park KC, Gaze DC, Collinson PO, Marber MS. Cardiac troponins: from myocardial infarction to chronic disease. Cardiovasc Res. (2017) 113:170818. doi: $10.1093 / \mathrm{cvr} / \mathrm{cvx} 183$

247. Richeldi L, du Bois RM, Raghu G, Azuma A, Brown KK, Costabel U, et al. Efficacy and safety of nintedanib in idiopathic pulmonary fibrosis. $N$ Engl J Med. (2014) 370:2071-82. doi: 10.1056/NEJMoa1402584

248. King TE, Bradford WZ, Castro-Bernardini S, Fagan EA, Glaspole I, Glassberg $\mathrm{MK}$, et al. A phase 3 trial of pirfenidone in patients with idiopathic pulmonary fibrosis. N Engl J Med. (2014) 370:2083-92. doi: 10.1056/NEJMoa1402582

249. Karimi-Shah BA, Chowdhury BA. Forced vital capacity in idiopathic pulmonary fibrosis-FDA review of pirfenidone and nintedanib. $N$ Engl J Med. (2015) 372:1189-91. doi: 10.1056/NEJMp1500526

250. Kasam RK, Reddy GB, Jegga AG, Madala SK. Dysregulation of mesenchymal cell survival pathways in severe fibrotic lung disease: the effect of nintedanib therapy. Front Pharmacol. (2019) 10:532. doi: 10.3389/fphar.2019.00532

251. Su H, Yang M, Wan C, Yi LX, Tang F, Zhu HY, et al. Renal histopathological analysis of 26 postmortem findings of patients with COVID-19 in China. Kidney Int. (2020) 98:219-27. doi: 10.1016/j.kint.2020.04.003

252. Moodley Y, Ilancheran S, Samuel C, Vaghjiani V, Atienza D, Williams ED, et al. Human amnion epithelial cell transplantation abrogates lung fibrosis and augments repair. Am J Respir Crit Care Med. (2010) 182:643-51. doi: 10.1164/rccm.201001-0014OC

253. Ashcroft T, Simpson JM, Timbrell V. Simple method of estimating severity of pulmonary fibrosis on a numerical scale. J Clin Pathol. (1988) 41:467-70. doi: $10.1136 /$ jcp. 41.4 .467

254. He F, Zhou A, Feng S. Use of human amniotic epithelial cells in mouse models of bleomycin-induced lung fibrosis: a systematic review and metaanalysis. PLoS ONE. (2018) 13:1-17. doi: 10.1371/journal.pone.0197658

255. Gad ES, Salama AAA, El-Shafie MF, Arafa HMM, Abdelsalam RM, Khattab M. The anti-fibrotic and anti-inflammatory potential of bone marrow-derived mesenchymal stem cells and nintedanib in bleomycin-induced lung fibrosis in rats. Inflammation. (2020) 43:123-34. doi: 10.1007/s10753-019-01101-2

256. Chen S, Cui G, Peng C, Lavin MF, Sun X, Zhang E, et al. Transplantation of adipose-derived mesenchymal stem cells attenuates pulmonary fibrosis of silicosis via anti-inflammatory and anti-apoptosis effects in rats. Stem Cell Res Ther. (2018) 9:110. doi: 10.1186/s13287-018-0846-9

257. Chen S, Chen X, Wu X, Wei S, Han W, Lin J, et al. Hepatocyte growth factormodified mesenchymal stem cells improve ischemia/reperfusion-induced acute lung injury in rats. Gene Ther. (2017) 24:3-11. doi: 10.1038/gt.2016.64

258. Chen W, Wang S, Xiang H, Liu J, Zhang Y, Zhou S, et al. Microvesicles derived from human Wharton's Jelly mesenchymal stem cells ameliorate acute lung injury partly mediated by hepatocyte growth factor. Int J Biochem Cell Biol. (2019) 112:114-22. doi: 10.1016/j.biocel.2019.05.010

259. Gazdhar A, Temuri A, Knudsen L, Gugger M, Schmid RA, Ochs M, et al. Targeted gene transfer of hepatocyte growth factor to alveolar type II epithelial cells reduces lung fibrosis in rats. Hum Gene Ther. (2013) 24:105-16. doi: 10.1089/hum.2012.098

260. Zhao Y, Lan X, Wang Y, Xu X, Lu S, Li X, et al. Human endometrial regenerative cells attenuate bleomycin-induced pulmonary fibrosis in mice. Stem Cells Int. (2018) 2018:1-13. doi: 10.1155/2018/3475137
261. Ni K, Liu M, Zheng J, Wen L, Chen Q, Xiang Z, et al. PD-1/PD-L1 pathway mediates the alleviation of pulmonary fibrosis by human mesenchymal stem cells in humanized mice. Am J Respir Cell Mol Biol. (2018) 58:684-95. doi: 10.1165/rcmb.2017-0326OC

262. Zhang E, Yang Y, Chen S, Peng C, Lavin MF, Yeo AJ, al. Bone marrow mesenchymal stromal cells attenuate silica-induced pulmonary fibrosis potentially by attenuating $\mathrm{Wnt} / \beta$-catenin signaling in rats. Stem Cell Res Ther. (2018) 9:1-14. doi: 10.1186/s13287-018-1045-4

263. Li F, Han F, Li H, Zhang J, Qiao X, Shi J, et al. Human placental mesenchymal stem cells of fetal origins-alleviated inflammation and fibrosis by attenuating MyD88 signaling in bleomycin-induced pulmonary fibrosis mice. $\mathrm{Mol}$ Immunol. (2017) 90:11-21. doi: 10.1016/j.molimm.2017.06.032

264. Li X, Li C, Tang Y, Huang Y, Cheng Q, Huang X, et al. NMDA receptor activation inhibits the antifibrotic effect of BM-MSCs on bleomycin-induced pulmonary fibrosis. Am J Physiol Lung Cell Mol Physiol. (2018) 315:404-21. doi: 10.1152/ajplung.00002.2018.-Endogenous

265. Cao H, Wang C, Chen X, Hou J, Xiang Z, Shen Y, et al. Inhibition of Wnt/ $\beta$ catenin signaling suppresses myofibroblast differentiation of lung resident mesenchymal stem cells and pulmonary fibrosis. Sci Rep. (2018) 8:13644. doi: 10.1038/s41598-018-28968-9

266. Chambers DC, Enever D, Ilic N, Sparks L, Whitelaw K, Ayres J, et al. A phase $1 \mathrm{~b}$ study of placenta-derived mesenchymal stromal cells in patients with idiopathic pulmonary fibrosis. Respirology. (2014) 19:1013-18. doi: $10.1111 /$ resp. 12343

267. Averyanov A, Koroleva I, Konoplyannikov M, Revkova V, Lesnyak V, Kalsin V, et al. First-in-human high-cumulative-dose stem cell therapy in idiopathic pulmonary fibrosis with rapid lung function decline. Stem Cells Transl Med. (2020) 9:6-16. doi: 10.1002/sctm.19-0037

268. Lan Y-W, Theng S-M, Huang T-T, Choo K-B, Chen C-M, Kuo H$\mathrm{P}$, et al. Oncostatin $\mathrm{M}$-preconditioned mesenchymal stem cells alleviate bleomycin-induced pulmonary fibrosis through paracrine effects of the hepatocyte growth factor. Stem Cells Transl Med. (2017) 6:1006-17. doi: 10.5966/sctm.2016-0054

269. Ayaub EA, Dubey A, Imani J, Botelho F, Kolb MRJ, Richards CD, et al. Overexpression of OSM and IL-6 impacts the polarization of pro-fibrotic macrophages and the development of bleomycin-induced lung fibrosis OPEN. Sci Rep. (2017) 7:1-16. doi: 10.1038/s41598-017-13 $511-\mathrm{z}$

270. Li D, Liu Q, Qi L, Dai X, Liu H, Wang Y. Low levels of TGF$\beta 1$ enhance human umbilical cord-derived mesenchymal stem cell fibronectin production and extend survival time in a rat model of lipopolysaccharide-induced acute lung injury. Mol Med Rep. (2016) 14:168192. doi: 10.3892/mmr.2016.5416

271. Chen S, Chen L, Wu X, Lin J, Fang J, Chen X, et al. Ischemia postconditioning and mesenchymal stem cells engraftment synergistically attenuate ischemia reperfusion-induced lung injury in rats. J Surg Res. (2012) 178:81-91. doi: 10.1016/j.jss.2012.01.039

272. Wu J, Song D, Li Z, Guo B, Xiao Y, Liu W, et al. Immunity-and-matrixregulatory cells derived from human embryonic stem cells safely and effectively treat mouse lung injury and fibrosis. Cell Res. (2020) 30:1-16. doi: 10.1038/s41422-020-0354-1

273. Cunha LL, Perazzio SF, Azzi J, Cravedi P, Riella LV. Remodeling of the immune response with aging: immunosenescence and its potential impact on COVID-19 immune response. Front Immunol. (2020) 11:1748. doi: 10.3389/fimmu.2020.01748

Conflict of Interest: The authors declare that the research was conducted in the absence of any commercial or financial relationships that could be construed as a potential conflict of interest.

Copyright (c) 2020 Ellison-Hughes, Colley, O'Brien, Roberts, Agbaedeng and Ross. This is an open-access article distributed under the terms of the Creative Commons Attribution License (CC BY). The use, distribution or reproduction in other forums is permitted, provided the original author(s) and the copyright owner(s) are credited and that the original publication in this journal is cited, in accordance with accepted academic practice. No use, distribution or reproduction is permitted which does not comply with these terms. 